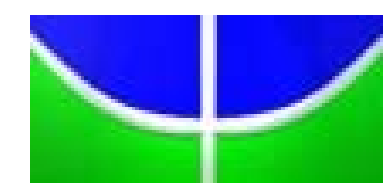

Universidade de Brasília - UnB

Centro de Excelência em Turismo - CET

Pós-graduação Lato Sensu

Curso de Especialização em Gastronomia como Empreendimento

\title{
CAPACITAÇÃO DE CONFEITEIROS E PADEIROS: UM ESTUDO DE VIABILIDADE PARA A CRIAÇÃO DE UM CENTRO DE TREINAMENTO ESPECIALIZADO
}

Maria da Penha Cordeiro Pereira 


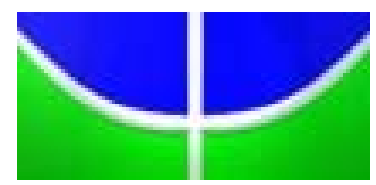

Universidade de Brasília - UnB

Centro de Excelência em Turismo - CET

Pós-graduação Lato Sensu

Curso de Especialização em Gastronomia como Empreendimento

\section{CAPACITAÇÃO DE CONFEITEIROS E PADEIROS: UM ESTUDO DE VIABILIDADE PARA A CRIAÇÃO DE UM CENTRO DE TREINAMENTO ESPECIALIZADO}

Maria da Penha Cordeiro Pereira

Orientadora: MSc Shirley Pontes

Co-Orientadora: MSc Raquel Botelho

Brasília, 2006 
Universidade de Brasília - UnB

Centro de Excelência em Turismo - CET

Pós-graduação Lato Sensu

Curso de Especialização em Gastronomia como Empreendimento

\section{CAPACITAÇÃO DE CONFEITEIROS E PADEIROS: UM ESTUDO DE VIABILIDADE PARA A CRIAÇÃO DE UM CENTRO DE TREINAMENTO ESPECIALIZADO}

Maria da Penha Cordeiro Pereira

Dra. Rita Akutsu

Coordenadora
MSc Shirley Pontes

Orientadora
Examinador

"Trabalho apresentado em cumprimento às exigências acadêmicas parciais do curso de pós-graduação lato sensu em Gastronomia como Empreendimento para a obtenção do grau de Especialista" 
Dedico esta monografia ao meu marido e grande amigo, por todo incentivo, paciência e colaboração e aos meus filhos pelo estímulo e apoio dedicado durante toda a minha jornada, e ao meu pai que, seguramente, sempre olha por mim onde quer que ele esteja. 


\section{AGRADECIMENTOS}

Agradeço à minha orientadora Shirley, pelo incentivo e por dividir comigo um pouco do seu conhecimento e de sua experiência.

Um agradecimento especial à Regina, pela colaboração neste projeto.

Agradeço também aos colegas de trabalho que me ajudaram a concluir este trabalho. 
Se a gula é um pecado capital, então o Brasil já nasceu pecador. Antes mesmo de ter um imperador próprio ou de definir as cores de sua bandeira, o país caiu de boca em tachos e mais tachos de fabulosas compotas, bolos e outros doces que a famosa criatividade tupiniquim tratou de inventar tão logo os portugueses desembarcaram aqui. (PEREIRA, s.d). 


\section{RESUMO}

Este estudo analisa sinteticamente a origem da Gastronomia, a origem e a produção do açúcar até a influência do açúcar na culinária. Posteriormente, descreve a história das confeitarias e enfatiza a necessidade de um treinamento profissionalizante especializado no setor de confeitaria e panificação, que de acordo com pesquisa de mercado realizada, carece de mão-de-obra qualificada e aperfeiçoamento técnico para atender as atuais demandas do mercado competitivo. Para tanto, é proposto neste estudo a criação de um Centro Técnico de Treinamento em Confeitaria e Panificação que viabilize a capacitação e o aprimoramento de conhecimentos práticoteóricos que concretizem o desenvolvimento profissional.

Palavras-chaves: Gastronomia; Açúcar; Confeitaria; Panificação; Qualificação Profissional; Treinamento. 


\begin{abstract}
This study it analyzes the origin of the Gastronomy, the origin and the production of the sugar until the influence of the sugar in the culinary. Later, it describes the history of the confectioneries and emphasizes the necessity of a specialized professionalizing training in the sector of confectionery and panification, that research of market in accordance with carried through, lacks of qualified man power and perfectioning technician to take care of the current demands of the competitive market. Considered in this study the creation of a Center Technician of Training in Confectionery and panification that makes possible the qualification and the improvement of knowledge practicaltheoreticians who materialize the professional development.
\end{abstract}

Key-words: Gastronomy; Sugar; Confectionery; Panification; Professional Qualification; Training. 


\section{LISTA DE TABELAS}

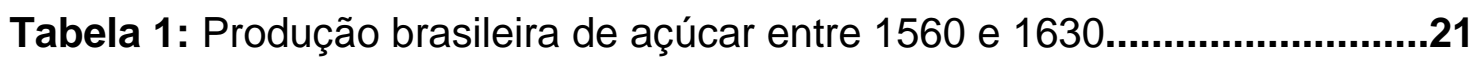

Tabela 2: Naturalidade da população segundo as Grandes Regiões, Distrito Federal e Entorno, 2004................................................................................................... 41

Tabela 3: Número de estabelecimentos do setor de Panificação e Confeitaria...........44

Tabela 4: Ranking de motivos para se consumir em padarias............................49,50

Tabela 5: Oferta dos cursos na área de panificação, confeitaria e salgados...............57

Tabela 6: Oferta dos cursos de qualificação/ aperfeiçoamento na área de panificação, confeitaria e salgados. $.58,59$

Tabela 7: Relação de preços das máquinas, equipamentos e utensílios...................71 


\section{LISTA DE GRÁFICOS}

Gráfico 1: Faturamento anual das empresas do setor de confeitaria e panificação...45

Gráfico 2: Composição média da receita das padarias / confeitarias.. .46

Gráfico 3: Alocação dos custos das padarias / confeitarias. .47 


\section{LISTA DE FIGURAS}

Figura 1: Planta Baixa do Centro Técnico de Treinamento...............................66

Figura 2: Medidas dos Laboratórios de Panificação e Confeitaria....................67

Figura 3: Sala de Aula.............................................................................68

Figura 4: Área destinada às atividades administrativas e acadêmicas.............69

Figura 5: Legenda da planta do Centro Técnico de Treinamento em Confeitaria e Panificação..................................................................................................70 


\section{SUMÁRIO}

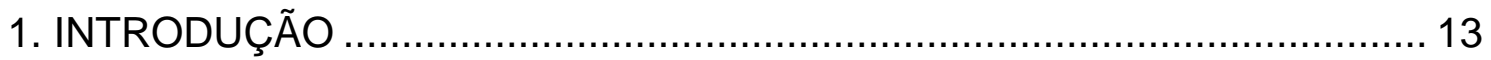

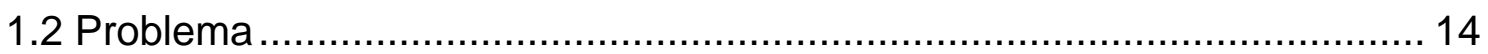

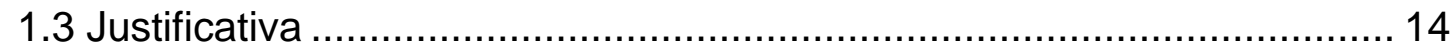

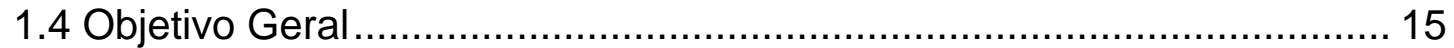

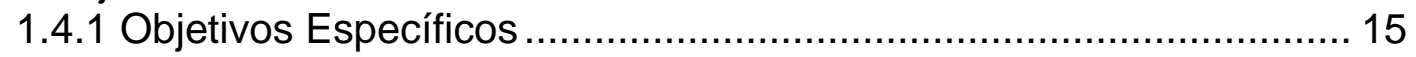

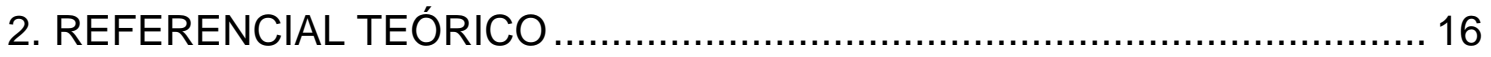

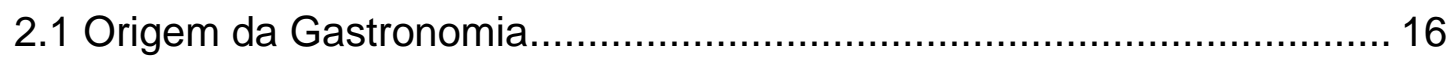

2.1.1 Influência dos Imigrantes na Gastronomia Brasileira ........................ 18

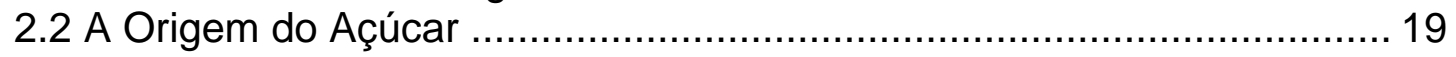

2.2.1 A cana-de-açúcar no Brasil ........................................................ 20

2.2.2 A Influência do Açúcar na Culinária ............................................... 22

2.2.3 A Produção do Açúcar ................................................................. 23

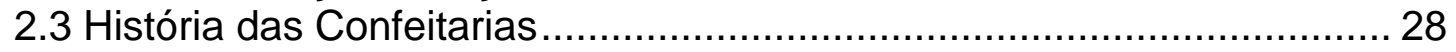

2.3.1 Treinamento Profissionalizante .............................................. 34

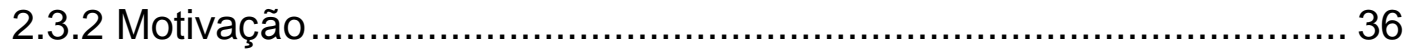

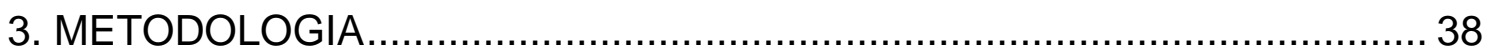

4. ANÁLISE MERCADOLÓGICA DO RAMO DE CONFEITARIA E

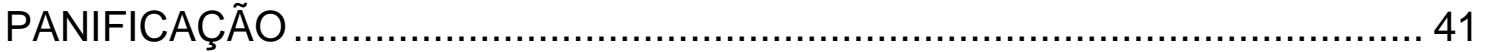

4.1 Dimensão do Setor de Confeitaria e Panificação .................................. 42

4.2 Panorama Econômico-Financeiro das Empresas ................................. 44

4.3 Evolução e Tendências dos Estabelecimentos de Confeitaria e

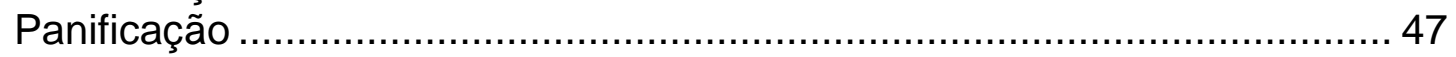

4.4 Perfil e Preferências dos Consumidores............................................... 49

4.5 Panorama do Setor no Distrito Federal.............................................. 50

4.6 Instituições Responsáveis pelo Desenvolvimento do Ramo de

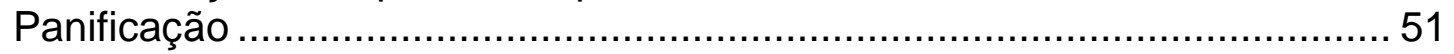

4.7 Empresas Concorrentes na Capacitação de Profissionais ....................... 56

4.8 Benchmarking em Confeitaria na América Latina ..................................... 60

5. PROPOSTA PARA CRIAÇÃO DO CENTRO TÉCNICO DE TREINAMENTO

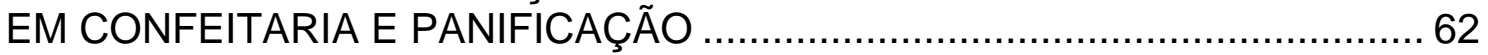

5.1 Objetivo do Centro Técnico de Treinamento ……................................. 62

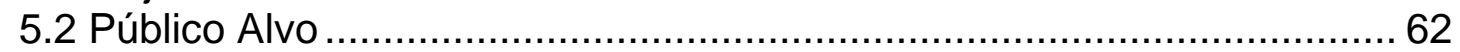

5.3 Metodologia de Ensino do Centro Técnico de Treinamento ....................63 63

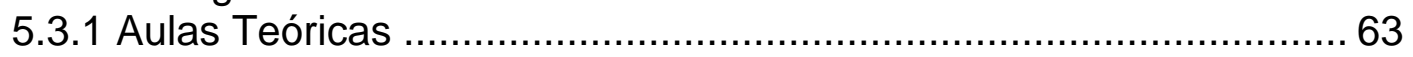

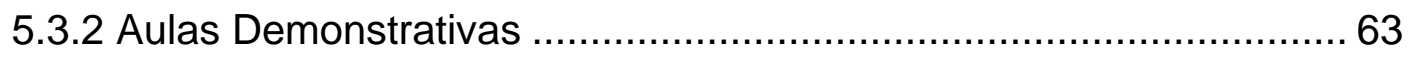

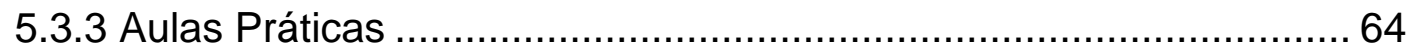

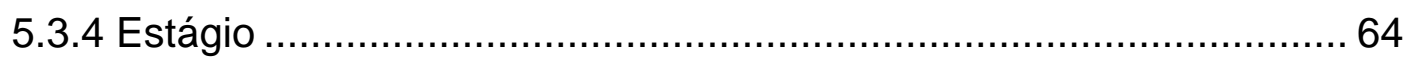

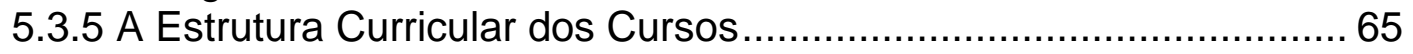

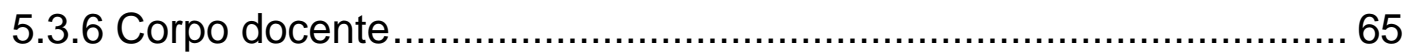

5.4 Lay Out do Centro de Capacitação.......................................................... 66 
5.5 Custo das Máquinas e Equipamentos do Centro Técnico de Treinamento 71

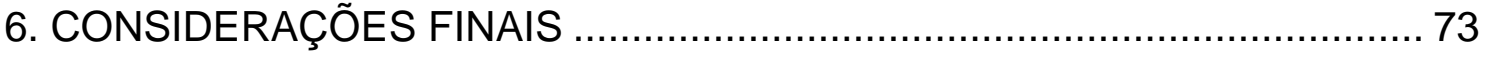

7. REFERÊNCIAS BIBLIOGRÁFICAS ................................................. 77 


\section{INTRODUÇÃO}

Este trabalho configura-se como um estudo de viabilidade para a implantação de um Centro de Treinamento Técnico destinado à capacitação de confeiteiros e padeiros no Distrito Federal.

Estudo recente, conduzido por Arbache (2004), apresentado no I Congresso Brasileiro de Gastronomia e Segurança Alimentar, demonstra que no setor de alimentação, em Brasília, apenas 22\% da mão de obra é qualificada, e igual percentual está na categoria semi-qualificada. A grande maioria ou seja 56\% é constituída por mão-de-obra não qualificada.

Segundo Furtado (2005), é indiscutível o crescimento da gastronomia em Brasília, nos últimos tempos, apesar da mão-de-obra qualificada ser um fator restritivo no mercado. As empresas consolidadas terão que estar sempre melhorando seus cardápios e diversificando-os para manter a clientela e conquistar novos clientes. $\mathrm{Na}$ área de confeitaria onde a evolução tem sido uma constante e o cliente está cada dia mais exigente "tem que ter variedade, novidade", fazendo com que os empresários busquem acompanhar e divulgar as novidades do setor.

No caso particular da confeitaria, cujo mercado é altamente competitivo, exigindo dos empresários novos conhecimentos e utilização de tecnologias mais avançadas, é necessário uma postura diferenciada para enfrentar a concorrência, em relação aos produtos e serviços ofertados. E isto está diretamente relacionado com a capacitação da mão-de-obra utilizada, que é o escopo de um centro de treinamento, visando atender as necessidades do 
mercado local e ensinando o que os profissionais precisam para se tornar mais qualificados para o desempenho de suas atividades.

\subsection{Problema}

O Problema de pesquisa desse estudo é analisar a viabilidade de criação de um Centro de Treinamento para Confeiteiros e Padeiros no Distrito Federal.

\subsection{Justificativa}

Na área específica de confeitaria e panificação, o surgimento de novos produtos, novos insumos e novas técnicas de produção é uma constante, o que implica na necessidade de atualização contínua das empresas, e conseqüentemente dos seus empregados.

O mercado de confeitaria e panificação está sempre inovando e exige dos empresários uma postura diferenciada em relação aos produtos e serviços oferecidos para fazer frente à concorrência em Brasília. Por isso é necessário buscar a cada dia novos conhecimentos e a utilização de tecnologia de ponta.

Os empresários, muitas vezes não têm consciência da necessidade de capacitar a mão-de-obra utilizada, o que é o escopo de um centro de treinamento, como o aqui proposto, visando atender as necessidades do mercado local.

O trabalho foi desenvolvido tomando como base os dados mais próximos da realidade, já que a pesquisadora teve 11 anos de experiência empresarial nesse ramo com as empresas: Confeitaria Arte \& Açúcar e Confeitaria Pit, portanto os problemas aqui relatados e estudados reproduzem 
a realidade do mercado e um verdadeiro interesse em contribuir para soluções efetivas com clareza e objetividade com situação do mercado local e ao mesmo tempo possibilitar a aplicação do conteúdo recebido ao longo do curso de "Gastronomia como Empreendimento".

\subsection{Objetivo Geral}

O objetivo geral desse estudo é analisar o mercado e a viabilidade da criação de um Centro de Treinamento na área de gastronomia voltado para formação de profissionais de confeitaria e panificação.

\subsubsection{OBJETIVOS ESPECÍFICOS}

- Realizar um levantamento histórico sobre a gastronomia e sobre o açúcar como insumo principal da confeitaria;

- Realizar uma pesquisa de campo para colher informações sobre as instituições que apóiam o desenvolvimento da gastronomia no Brasil;

- Efetuar análise mercadológica em relação às empresas que operam no ramo de confeitaria e panificação;

- Propor a criação de um centro de capacitação de mão-de-obra na atividade de confeitaria e panificação. 


\title{
2. REFERENCIAL TEÓRICO
}

\subsection{Origem da Gastronomia}

Conforme Zacaro, a palavra gastronomia vem do termo grego formado por Gaster (ventre, estômago), radical momo (lei) e sufixo (ia) de substantivo, ou seja, estudo e observância das leis do estômago.

\begin{abstract}
A gastronomia é definida como a arte de preparar as iguarias, tornando-as mais digestivas, de modo a obter o maior prazer a quem come. A definição de gastronomia passou a preceitos de comer e beber bem, tendo um sentido mais amplo. Mas existem definições de gastronomia como uma ciência, já que certas leis físico-químicas têm de ser observadas na preparação do alimento. (SENAC, s.d.).
\end{abstract}

A Gastronomia é a única arte que atua sobre os cinco sentidos, e a boa comida é aquela que mexe com a mente, a criatividade, enche os olhos e a boca. Então a proposta da Gastronomia é proporcionar prazer, relacionando a qualidade do alimento com as sensações despertadas em quem o ingere.

Em Gastronomia, tanto quem cozinha quanto quem come deve saber combinar tradição com a criação. A tradição está no saber do povo, é ligada à terra e à exploração dos produtos da região e das estações. Já a criação está relacionada à invenção, à inovação e às experimentações.

Quando se analisa a cozinha de determinada região, observa-se que ela deva ter a marca do passado, da história, e da sociedade, do povo e da nação a qual pertence.

Podem-se citar inúmeras receitas que conquistaram fama nacional, que foram nascidas em determinada região do Brasil e que são saboreadas nos bares e restaurantes mais tradicionais, além de marcarem uma época em que o Brasil estava vivendo. Tem-se como exemplo, um dos grandes articuladores 
da Revolução de 1930, Oswaldo Aranha, que criou um dos pratos mais famosos da cidade do Rio de Janeiro. A invenção entrou para a História: "Filé à Oswaldo Aranha". Toda semana, o grande político e estadista, amigo pessoal de Getúlio Vargas, almoçava no restaurante de nome Cosmopolita, na Lapa, na época mais conhecido como "Senadinho", pois era o ponto de encontro de políticos. Ao chegar, pedia um filé alto com muito alho e, para acompanhar arroz branco, farofa e batata portuguesa. As pessoas começaram a ver prato dele e pedir um igual. Fez tanto sucesso que passou a incorporar a receita no cardápio local e nacional, daí porque o "filé Oswaldo Aranha" saiu para conquistar o Brasil.

De acordo com Flandrin e Montanari (1998) a Alta Gastronomia surgiu com a marcante influência de Catarina de Médici, nascida na Itália, que trouxe o interesse das artes culinárias da França, em 1533. Nos séculos seguintes, as famílias reais empregaram chefes que prepararam pratos e desenvolveram técnicas culinárias do mais alto grau de refinamento e o ato de comer se tornou uma arte.

Apesar deste tipo de comida ser desconhecida e fora do alcance da população, emergiu rápido e alcançou o consumo popular após a revolução. A queda da aristocracia fez com que os chefes ficassem desempregados, dando surgimento à abertura dos primeiros restaurantes.

Segundo Fernandez-Armesto (2004), até a Revolução Francesa existiam cerca de 100 restaurantes em Paris, aumentando para mais de 500 após as mudanças sociais. As pessoas que até então não tinham tido oportunidades de experimentar uma trufa, passaram a desfrutar de uma série de iguarias. Os restaurantes se tornaram os templos da alta gastronomia. 


\subsubsection{INFLUÊNCIA DOS IMIGRANTES NA GASTRONOMIA BRASILEIRA}

Desde o descobrimento do Brasil, em 1500, aos dias de hoje muitos povos que aqui chegaram trouxeram muito de suas crenças, culturas e hábitos que, de certa forma, misturaram-se com a nossa cultura. Essa cultura, onde a gastronomia faz parte, fez com que cada imigrante que veio para o nosso país trouxesse sua preferência alimentar.

A Europa teve grande participação na cultura alimentar brasileira. Quando Pedro Álvares Cabral descobriu o Brasil, em uma de suas navegações, trouxe de regiões do Oriente, Índia, os condimentos (substâncias aromáticas que realçam o sabor dos alimentos), que passaram a ser utilizados pelos índios, localizados na cidade de Porto Seguro, na Bahia. Trouxe também, presunto, vinho, pão, cana-de-açúcar, entre outros. A participação espanhola e portuguesa se confunde na sua semelhança, pois os dois países tiveram influência dos árabes.

Mas foram os alemães os primeiros a fundarem colônias no sul do país, Santa Catarina, Paraná, Rio Grande do Sul, e também no Espírito Santo. O alemão não trouxe só a influência, mas um esforço de certas espécies que foram utilizadas pelos portugueses, como a cerveja e as carnes salgadas e defumadas.

De acordo com Flandrin e Montanari (1998), entre 1860 e 1890 desembarcaram 974 mil italianos no Brasil que trouxeram um gosto especial pelas massas com farinha de trigo, com molhos densos e condimentos. Ninguém conseguiu mudar a alimentação italiana que acabou participando, e muito, na gastronomia brasileira. 
Toda culinária nacional é formada por cozinhas regionais. No Brasil as influências foram muitas. A partir delas apareceram adaptações e variações, como a cozinha sertaneja, nordestina, caipira, mineira, gaúcha, da fazenda e outras. Hoje se tem uma nova era de pesquisas devido a atenção sobre a origem dos pratos, dos ingredientes e a evolução das receitas.

\subsection{A Origem do Açúcar}

Segundo Freyre (1977), a cana-de-açúcar é nativa do Sul do Pacífico, e daí ocorreram às migrações para várias regiões como para o sudeste da Ásia, para a Índia, para a China.

No decorrer da Idade Média o cultivo da cana-de-açúcar passou a ser difundido pelos Árabes no mundo mediterrâneo, nas terras conquistadas pelos muçulmanos, em particular na Sicília e Espanha.

Ainda de acordo com Freyre (1977), o gosto pelo açúcar não parava de se difundir pela Europa. Para satisfazer esse mercado nascente, as refinarias multiplicaram-se no século XV nas planícies costeiras da Sicília. Como a demanda continuava a crescer, os portugueses levaram a cana-de-açúcar e as técnicas de produção da Sicília para a llha da Madeira, tornando-se o principal fornecedor da Europa Ocidental, tendo chegado mesmo a uma superprodução. Em 1498, para evitar a queda dos preços do açúcar, o rei D. Manuel decidiu limitar as exportações da ilha a 120 mil arrobas, equivalentes a 1780 toneladas.

Além da ilha da Madeira, as Canárias, conquistadas pelos espanhóis em 1480, e São Tomé, colonizados pelos portugueses em 1483, tornaram-se também grandes produtoras de açúcar. 
No decorrer do século XVI o açúcar passou a ocupar um espaço cada vez mais importante entre os produtos exóticos vendidos pelos comerciantes de especiarias. $\mathrm{O}$ açúcar na Antiguidade era considerado uma mercadoria rara e cara e costumava ser encontrado nos boticários que o reservavam para quem estivesse doente, sendo prescrita pelos médicos. Usada com certa parcimônia, nos temperos era considerada uma especiaria e hoje é usado para produção de guloseimas; parafraseando Ortelius (1572) "O que outrora servia como medicamento, no presente serve-nos de alimento".

\subsubsection{A CANA-DE-AÇÚCAR NO BRASIL}

A introdução da cana-de-açúcar no Brasil se deu em meados do século $\mathrm{XV}$, oriunda da ilha da Madeira, de onde foi transplantada da Sicília, a mando do Infante Dom Henrique. Da ilha da Madeira, os portugueses levaram a cana ao Cabo Verde, aos Açores, a São Tomé. Tornando-se estas regiões grandes produtoras e distribuidoras de açúcar no mundo.

Os portugueses multiplicaram a plantação de cana-de-açúcar no Brasil, a partir de 1530 e segundo Freyre (1977), em 1532, foi erguido em São Vicente o primeiro engenho de açúcar. Dois anos depois foi construído em terras nordestinas, em Pernambuco, o segundo engenho, tornando essa região grande produtora e chegando até ultrapassar São Vicente, em importância e produção, devido à expansão dos engenhos por todo o Estado, moendo a cana e produzindo açúcar.

Para Cascudo (1968), a Coroa Portuguesa passou a estimular as plantações nessa região, devido às condições climáticas satisfatórias encontradas para o desenvolvimento da lavoura canavieira. Promoveu a 
distribuição de terras em sesmarias e isentando dos tributos que recaíam sobre o açúcar os colonos que formassem seus engenhos. O sucesso da cultura em terras nordestinas foi o pontapé inicial para o surgimento das primeiras organizações culturais na nova Colônia. Em função disso, os engenhos passaram a se organizar, sendo formados pela Casa-grande, que ficava sempre em uma área mais elevada, ao lado da Capela, próximo ao rio, a fábrica de moagem, local estratégico, porque dependiam exclusivamente da água para fabricação do açúcar e por fim a Senzala que abrigava os escravos.

Conforme Belluzzo e Heck (2002), com a produção do açúcar, o panorama do Brasil mudou, tornando-se o maior produtor e exportador durante anos, constituindo um marco na história, pois foi o maior colaborador para a independência econômica. O açúcar passou a ser fonte de lucro aos colonizadores como para os fazendeiros e, ainda, para os intermediários que faziam a comercialização.

Praticamente toda a produção brasileira de açúcar era enviada para a Europa. (Tabela 1). Depois o açúcar era enviado para Lisboa e, sobretudo para Antuérpia, tornando-se o grande centro de refinação e redistribuição do açúcar na Europa do Norte.

Tabela 1: Produção brasileira de açúcar entre 1560 e 1630.

\begin{tabular}{|l|l|}
\hline Ano 1560: & 2.470 toneladas \\
\hline Ano 1600: & 16.300 toneladas \\
\hline Ano 1630: & 20.400 toneladas \\
\hline
\end{tabular}

Fonte: Flandrin e Montanari, 1998.

O grande desenvolvimento do consumo do açúcar está associado aos hábitos dos europeus por três novas bebidas: o chocolate, o café e o chá. 


\subsubsection{A INFLUÊNCIA DO AÇÚCAR NA CULINÁRIA}

A primeira grande fonte de riqueza da nova Província veio justamente da produção de um dos ingredientes mais tentadores que é o açúcar. Freyre (1939) procurou relatar a forma como o açúcar influenciou os hábitos da época. Cita que a arte da doçaria brasileira se deve às donas de casa, às negras de cozinha e aos pretos doceiros. A origem do doce brasileiro é patriarcal e seu preparo foi sempre um dos rituais mais sérios da antiga vida de família das casas-grandes e dos sobrados, embora não faltassem freiras quituteiras que continuassem a tradição dos conventos portugueses.

Quando se fala na doçaria brasileira não se pode ignorar a importância do trabalho escravo.

Sem a escravidão não se explica o desenvolvimento, no Brasil, de uma arte doce, de uma técnica de confeitaria, de uma estética de mesa, de sobremesa de tabuleiro tão cheios de complicações e até de sutileza e exigindo tanto vagar, tanto lazer, tanta demora e tanto trabalho no preparo e nos enfeites dos doces, dos bolos, dos pratos, das toalhas e das mesas. Só o lazer das sinhás ricas e o trabalho fácil das negras e das antigas molecas explicam as exigências de certas receitas das antigas famílias das casas-grandes e dos sobrados, receitas quase impossíveis para os dias de hoje. (FREYRE, 1977).

Segundo Cascudo (1968), apesar do trabalho escravo ter sido muito importante no desenvolvimento da doçaria brasileira, quando eles desembarcaram na nova Colônia, não conheciam o açúcar; só vieram a conhecê-lo quando foram instaladas as primeiras moendas. O açúcar não fazia parte da dieta dos nativos, por isso o açúcar não determinou nenhuma guloseima indígena. Herdou-se deles outros produtos como a farinha de mandioca, de milho, de tapioca e de beiju. O autor cita ainda que: "[...] nenhum doce nasceu das mãos generosas das nossas índias. Açúcar e sal são valores da mulher branca". 
Segundo Belluzzio e Heck (2002), os doces eram preparados nas cozinhas das sinhazinhas, que trouxeram suas receitas tradicionais e passaram a ensinar a doçaria portuguesa para as negras que freqüentavam as cozinhas das casas-grandes, e que acabaram se tornando especialistas na arte da confeitaria. Carentes de produtos europeus passaram a adotar os produtos da terra que eram as suculentas frutas tropicais, o melado, a rapadura e o açúcar cristal.

A qualidade do açúcar produzido no nordeste juntou-se à variedade de frutas tropicais e de outros produtos, como a mandioca e, a partir daí a doçaria brasileira começou a desenvolver, formando uma união indissolúvel entre a fartura das frutas e o açúcar abundante.

A fartura do açúcar estimulou o uso amplo de doces. Era com o açúcar que se arredondava a gordura dos frades e das sinhás-moças, sublinhou Gilberto Freyre em Casa-Grande \& Senzala. Contudo, além desse fator, não se deve esquecer a influência lusitana, cuja cozinha sempre foi extremamente rica na doçaria. A propósito, o autor faz interessante associação entre doces e erotismo, presente nas formas fálicas e nomes como beijinho, papo-de-anjo, manjar-do-céu, suspiro-de-freira, entre outros.

Ele destacou essa característica como reflexo da necessidade de se manter intensa atividade procriadora no império português para se povoar as novas terras conquistadas.

\subsubsection{A PRODUÇÃO DO AÇÚCAR}

De acordo com Freyre (1977), a fabricação do açúcar naquela época ocorria da seguinte forma: as canas eram trituradas em moendas de dois 
cilindros verticais de madeira, movidos por roda d'água ou tração animal, de onde se extraía o caldo e retirava-se o bagaço. No entanto, era necessária uma segunda espremedura para que se obtivesse um caldo mais grosso, e para isso usavam-se pilões e monjolos. O caldo era levado para a casa das caldeiras e fervido em grandes tachos de cobre ou de ferro batido até engrossar, mexido com enormes escumadeiras de madeira, com as quais se retirava a espuma que se formava e se retiravam as impurezas. O melaço era despejado em caçambas de madeiras e carregado à casa de purgar. Sob os olhares atentos do mestre purgador, os escravos transferiam o melaço para as formas de barro e as encaixavam em uma grande mesa de madeira e o tendal com buracos circulares. As formas permaneciam no tendal por vários dias, até a cristalização do açúcar. O açúcar produzido não era muito branco, pois, quanto mais alvo ele fosse, mais caro ficava e maior prestígio o produtor adquiria. Apesar disso, as técnicas de refinamento foram se aperfeiçoando.

Atualmente os processos utilizados na fabricação do produto evoluíram, não só no que se refere ao cultivo da matéria-prima, mas, sobretudo ao seguimento industrial, especificamente a produção do açúcar. Neste particular foram introduzidas novas técnicas industriais responsáveis por elevados índices de produtividade.

A safra da cana-de-açúcar é sazonal iniciando em maio e terminando em novembro. Neste período ocorre o amadurecimento da cana devido a fatores climáticos como falta de umidade, luminosidade e frio. Com o amadurecimento, as canas passam a ser cortadas de forma planejada. Através do controle e planejamento dos canaviais, é montado um programa de corte baseado na maturação da cana. Dessa forma, têm-se áreas com cana plantada que estará 
própria para o corte em momentos diferentes, o que permite seu manejo. $\mathrm{O}$ corte feito manualmente representa $50 \%$ da cana colhida. Os outros $50 \%$ são colhidos por colhedeira ${ }^{1}$.

O transporte até a unidade industrial é feito por caminhões. Cada carga transportada pesa aproximadamente 16 toneladas. Hoje há caminhões com capacidade de até três ou quatro carrocerias em conjunto, aumentando muito a capacidade do transporte. Depois de cortada e transportada para a usina, a cana-de-açúcar é enviada para a moagem, onde se inicia o processo de fabricação do açúcar ${ }^{2}$.

A cana que chega à unidade industrial é processada o mais rapidamente possível. Este sincronismo entre o corte, o transporte e a margem são importantes, pois a cana é uma matéria-prima sujeita a contaminações e conseqüentemente de fácil deterioração.

Antes da moagem, a cana é lavada nas mesas alimentadoras para retirar a terra proveniente da lavoura. Após a lavagem, a cana passa por picadores que trituram os colmos, preparando-a para a moagem. Neste processo as células de cana são abertas sem perda do caldo. Após o preparo, a cana desfibrada é enviada à moenda para ser moída e extrair o caldo. $\mathrm{Na}$ moenda, a cana desfibrada é exposta entre rolos submetidos a uma pressão de aproximadamente $250 \mathrm{Kg} / \mathrm{cm}^{2}$, expulsando o caldo do interior das células. Este processo é repetido por seis vezes continuamente. Adiciona - se água numa proporção de $30 \%$. A isto se chama embebicão composta, cuja função é embeber o interior das células da cana diluindo o açúcar ali existente e com isso aumentando a eficiência da extração, conseguindo-se assim extrair cerca

\footnotetext{
${ }_{1}^{1}$ Informações colhidas no site http://www.acucarguarani.com.br

2 Informações colhidas no site http://www.usinaester.com.br
} 
de $96 \%$ do açúcar contido na cana. O caldo extraído vai para o processo de tratamento do caldo e o bagaço para as caldeiras. Nas caldeiras, o bagaço é queimado para gerar vapor, que é utilizado no acionamento das máquinas pesadas, geração de energia elétrica e no processo de fabricação do açúcar ${ }^{3}$.

O caldo extraído da moenda, chamado de caldo misto, é um caldo impuro, sendo necessário passar, por um processo de clarificação para retirada de sólidos em suspensão. O caldo é sulfatado e caleado. Este processo é chamado de dosagem. A adição de enxofre e cal facilita a floculação das substancias coloidais.

Após a dosagem, o caldo é aquecido a $107^{\circ} \mathrm{C}$ em aquecedores verticais e enviado aos clarificadores que retêm o caldo por aproximadamente três horas em regime contínuo. Neste tempo de retenção, ocorrem reações de floculação e precipitação do material em suspensão que são retirados na forma de lodo. O caldo clarificado e limpo segue o processo para evaporação e o lodo irá para filtração a vácuo onde é recuperada a sacarose ainda existente. O lodo é rico em sacarose, por isso é feito uma filtração nos filtros rotativos a vácuo para seccionar o material líquido, chamado de caldo filtrado, que sofrerá novo tratamento de clarificação, o material sólido retido nas telas dos filtros é denominado torta de filtro. Esta torta é enviada à lavoura, sendo utilizada como adubo.

O caldo clarificado com aproximadamente $15^{\circ}$ Brix entra em um conjunto de evaporadores de múltiplo efeito para retirada de $65^{\circ}$ Brix, tomando consistência de um xarope.

\footnotetext{
${ }^{3}$ Informações colhidas do site http://www.usinaester.com.br
} 
Este xarope clarificado é bombeado aos tachos de cozimento onda dará continuação à evaporação do xarope, tornando o meio supersaturado dando as condições necessárias à cristalização do xarope, O produto obtido neste cozimento forma uma massa. Esta massa é uma mistura de cristais de açúcar de aproximadamente $0,5 \mathrm{~mm}$ envolvidos numa película de mel. $\mathrm{Na}$ centrifugação ocorre à separação do mel e o seu licor corresponde licor-mãe. No cozimento os tachos recebem o mel e por um processo de nucleação, produzem-se os pequenos cristais de aproximadamente $0,2 \mathrm{~mm}$ e melaço, de modo controlado e padronizado. Este processo é fundamental na qualidade do produto final, onde todos os cristais são induzidos a uma formação conjunta e uniforme, chamado de semeamento total ${ }^{4}$.

$\mathrm{Na}$ etapa seguinte o açúcar passa no secador para a retirada da umidade contida nos cristais. Na saída do secador, o açúcar é enviado por esteiras sanitárias até a moega do açúcar, que é o reservatório próprio para receber o açúcar, de onde é feito o ensacamento, podendo ser em sacos de 50 Kg ou em contêineres "big-bag" de 100 Kg.

Entre os vários tipos de açúcar hoje produzidos no Brasil destacam-se o açúcar refinado granulado, o açúcar refinado amorfo, o glaçúcar, o xarope invertido e o açúcar orgânico. Para as confeitarias, o açúcar tipo refinado amorfo e o glaçúcar são mais utilizados como matéria-prima devido as suas características.

O açúcar refinado amorfo tem baixa cor, dissolução rápida, granulometria fina e brancura excelente. É utilizado no consumo doméstico, em

\footnotetext{
${ }^{4}$ Informações colhidas no site http://www.usinaester.com.br
} 
misturas sólidas de dissolução instantânea, bolos e confeitos, caldas transparentes e incolores.

O glaçúcar também conhecido como o açúcar de confeiteiro, tem grânulos bem finos, cristalino e destinado à indústria alimentícia, que o utiliza em massas, biscoitos, confeitos e bebidas. É misturado com amido de milho para evitar a cristalização.

Já o xarope invertido possui $1 / 3$ de glicose, $1 / 3$ de frutose e 1/3 de sacarose, solução aquosa com alto grau de resistência à contaminação microbiológica, é utilizado em frutas em calda, sorvetes, balas e caramelos, licores, geléias, biscoitos.

A produção brasileira de açúcar no ano 2002/2003 foi cerca de 281.042.145 milhões de toneladas, das quais $60 \%$ ou seja, 168.625.287 milhões foram produzidas no Estado de São Paulo, considerado o maior produtor do país. Para a safra 2004/2005 a estimativa de produção, na região Centro-Sul está em torno de 22,6 milhões de toneladas ${ }^{5}$.

Cerca de $50 \%$ da produção brasileira é destinado ao mercado externo, sendo a Rússia o maior cliente do Brasil.

\subsection{História das Confeitarias}

Segundo Leal (1998), com as descobertas de novas terras e condições geográficas e climáticas favoráveis à monocultura do açúcar, Portugal pôde, como os árabes, contribuir para a expansão, popularização e utilização do açúcar na construção das doçarias.

\footnotetext{
${ }^{5}$ Informações colhidas no site http//:www.unica.com.br
} 
De acordo com Consiglieri (1999), quando se fala em doçaria, em suas origens e espécies, são inevitáveis as referências à tradição portuguesa de confecção. E os conventos foram, não há dúvida, os grandes responsáveis pela difusão de receitas (ou nomes) que circulam no quotidiano do doce português.

No entanto, o autor brasileiro Cascudo (1971) afirma que os conventos não tinham o monopólio da doçaria portuguesa, "[...] sempre se fazia doces nas aldeias e vilas, nas cidades e quintas. Doces fiéis às festas do ano e às alegrias das comemorações familiares" Consiglieri (1999) completa dizendo que "[...] também os palácios assim como, casas de famílias (primeiro) e os profissionais (depois) os fizeram ao longo de séculos, graças às referências e influências de seus antecessores".

A cozinha portuguesa, em particular de doçaria portuguesa, é resultado das interações entre doçaria popular, doçaria conventual e doçaria palaciana. Estas interações foram sendo cada vez mais íntimas, resultando numa doçaria única, mundialmente conhecida e apreciada.

Para Cascudo (1971), a comercialização do açúcar generalizou-se a partir do século XVI em Portugal, ao contrário de outros países onde o hábito de se utilizar este produto só se verificou no século XVII. A antecipação na utilização deste produto permitiu o desenvolvimento de uma doçaria variada.

De acordo com Perrella (1999), a doçaria adquiriu tamanho prestígio que em Lisboa, ao virar o século XVI, já existia a Rua dos Confeiteiros, na paróquia de S. Nicolau. O regulamento dos Confeiteiros era datado de 12 de novembro de 1575 e estabelecia os princípios e orientações da atividade nos seus 28 artigos, com informações detalhadas sobre a fabricação de doces. 
Para Consiglieri (1999), na Lisboa Joanina a doçaria manteve basicamente as mesmas características do século anterior, acentuando-se a predominância dos açúcares sobre o mel. Entretanto, na cidade, as lojas de confeitarias e as de bebidas consolidavam o seu prestígio. A par dos cafés e dos botequins apareceram às chocolatarias. Ao lado dos bolos antigos, surgem as bolachas de perfeita fabricação, bastante elaboradas e cujo sabor conquista novas clientelas, particularmente os que preferem as bolachas de chá.

Saramago \& Fialho (1977) observaram as grandes mudanças ocorridas no século XVII, na gastronomia em geral, e na doçaria em particular, onde foram importantes as influências, culturais e sociais. Então, a confeitaria manufatureira que utilizava um modo de trabalho artesanal, utilizando-se de moinhos à força braçal, transforma-se em pequenas oficinas com apoio de máquinas de confeitaria, fornos e fogões de produção em série.

A expansão marítima provocou um enorme intercâmbio cultural entre os europeus e aqueles com os quais mantiveram contato na Ásia, no Brasil, na América, na África.

Segundo Leal (1988), os navegadores levavam sementes, raízes e cereais para as terras distantes e, de volta, traziam as novidades lá experimentadas. $E$ assim os europeus aprenderam e também ensinaram o preparo de um mesmo alimento de maneiras diferentes, o uso de novos temperos, a combinação de diversos sabores e o cultivo dos mais variados produtos. E o resultado de tudo isso foi uma troca muito saudável de alimentos e receitas. Quando as plantações de cana-de-açúcar passaram a ser produzidas na América, o açúcar tornou-se mais acessível e barato. E aos poucos ele foi substituindo o mel, pois se adaptava melhor ao uso culinário. E 
assim, ele acabou influenciando consideravelmente os hábitos das populações que o cultivavam.

Conforme Lesnau (2004), o Renascimento foi a época das guloseimas, tendo os italianos e ingleses inovado na preparação de geléias, compotas e frutas cristalizadas, que os franceses desconheciam. Surgiram algumas obras francesas sobre confeitaria, sendo a mais interessante delas atribuídas ao célebre profeta Nostradamus.

Mas foi só no final do século XVII, que os doces passaram a vir todos os dias para as mesas da Europa; anteriormente eram servidos somente nos dias de festa e passaram a ser produzidos em grandes variedades pela pastelaria francesa, como destacou Leal (1998). Uma novidade que revolucionou a sobremesa da época foi o sorvete, que logo se tornou popular na França. Também a pastelaria de Viena, capital da Áustria, começou a fazer fama, sendo o apfelstrudel uma de suas especialidades.

Os doces preferidos do povo e da aristocracia do século XVII eram a tartellete amandine dos franceses e a queijadinha dos portugueses, um dos dois doces que permanecem até os dias atuais.

Ainda de acordo com Leal (1998), no século XVIII, a França inaugurou com Luís XV, uma cozinha elegante, que deixava a pompa um pouco de lado, tornando-se mais discreta que a do período anterior, despertando para a inteligência, inventividade e interesse pela boa mesa. Foi neste governo que a verdadeira cozinha francesa se firmou. Surgindo a nova cozinha, clássica e transformadora, que passou a exigir a capacitação de profissionais. 
A industrialização dos doces teve início no século XIX, e não teve grande influência na confeitaria artesanal, e, devido à criatividade dos confeiteiros, encontraram uma forma de fazer doces cada vez mais tentadores. No Brasil, a culinária é caracterizada pela concomitância de elementos da cozinha africana, portuguesa e indígena, sendo possível estabelecer distinção entre a influência africana que predomina principalmente nos pratos salgados; a influência indígena que fornece os acompanhamentos indispensáveis e prediletos na alimentação cotidiana do brasileiro e a portuguesa se faz notar principalmente nos doces, cujas receitas mantidas pelas freiras chegaram até nós. Deles herdou-se a produção com a abundância e as variedades.

Para Andrade (2002), a mão da mulher portuguesa valorizou o sabor das iguarias triviais com um toque europeu e tornou a farinha de mandioca alimento diário. Fez o beiju mais fino e molhado com leite. E os primeiros bolos brasileiros com leite de vaca e ovo foram elas que introduziram em nossa doçaria.

A comercialização dos doces no Brasil começou com as escravas que vieram a ser escravas de ganho. Iam para a rua com tabuleiros, vender doces e quitutes, pagando ao senhor certa quantia estabelecida.

Por volta de 1890, a sociedade vislumbrava o início de uma nova década, com uma nova República. O Rio de Janeiro passou a ter um crescimento cultural muito acelerado, devido à influência dos artistas e escritores europeus. Então surge, em 1894, à Rua Gonçalves Dias, a Confeitaria Colombo, que passou a ser o ponto de encontro de intelectuais e políticos para discutirem os assuntos do momento e também degustar os maravilhosos doces, café, salgadinhos da confeitaria. Seus salões luxuosos 
foram freqüentados por Olavo Bilac, Rui Barbosa, Chiquinha Gonzaga, Villa Lobos, Virgínia Leme, Getúlio Vargas, dentre outros. Esse é um exemplo de empreendedores de sucesso há mais de um século e que pode ser visitado trazendo aos dias de hoje ares e aromas do século XIX .

Outra história de sucesso nesta área é a da confeitaria Di Cunto, instalada há mais de 70 anos no bairro da Mooca, em São Paulo. O produto principal desta confeitaria é o famoso panettone. Faz tanto sucesso que tem de ser elaborado o ano inteiro, e vende mil unidades do produto por semana, porém na época do natal, a produção triplica, garante Galante (2005).

O mercado de confeitaria no Brasil está sempre em alta, principalmente quando se fala em turismo. Nas cidades que oferecem o serviço, suas casas estão sempre movimentadas e costumam lotar com a queda da temperatura. No Vale do Itajaí, a cidade de Brusque, de colonização alemã , é visitada pelos turistas à procura dos seus cafés coloniais e as confeitarias.

Conforme assinalado por Galante (2005), a Pâtisserie Douce France, localizada em São Paulo, tem como seu proprietário o mais consagrado pâtissier Fabrice Lenud em atividade no Brasil, prepara verdadeiras obras de arte.

Em Brasília, encontram-se várias confeitarias de sucesso, mas como exemplo cito a confeitaria Di Lorenza que foi inaugurada em julho de 1995, no setor Sudoeste, abrangendo área de produção e primeira loja de vendas. A empresa continuou crescendo, alicerçada no tripé de qualidade dos produtos, serviços e instalações. Atualmente os seus produtos são encontrados em oito lojas e são produzidos na Central de Produção Alimentos.

\footnotetext{
${ }^{6}$ Informação colhida do site http://www.imasters.com.br
} 


\subsubsection{TREINAMENTO PROFISSIONALIZANTE}

Para a boa formação profissional é necessário investimento em treinamento e envolvimento, pois são as grandes ferramentas de transformação nas organizações.

A aprendizagem de novos conceitos e suas aplicações é fundamental a uma realidade de constante evolução tecnológica que vem acompanhada por um mercado de trabalho globalizado e competitivo. Uma organização voltada para a melhoria contínua deve possuir como meta treinamento e desenvolvimento de seu pessoal, de forma a se gerar comprometimento da equipe em todos os níveis.

O mundo do trabalho está se alterando contínua e profundamente, pressupondo a superação das qualificações restritas às exigências de postos delimitados de trabalho ou emprego. Isso determina a necessidade de um novo modelo de educação profissional centrado no desenvolvimento de competências por área profissional. Torna-se cada vez mais essencial que o técnico tenha um perfil de qualificação que lhe permita construir itinerários profissionais, com mobilidade, ao longo de sua vida produtiva. Um competente desempenho profissional exige domínio do seu "ofício" associado à sensibilidade e à prontidão para mudanças e uma disposição para aprender, aprender a aprender e contribuir para o seu contínuo aperfeiçoamento e aprimoramento profissional.

A importância do treinamento segundo Rêgo (1997) é dar aos colaboradores conhecimentos prático-teóricos necessários ao desenvolvimento de habilidades requeridas pelo trabalho. 
Já Caravantes (1997) considera que o propósito do treinamento é dotar os integrantes da organização de conhecimentos e de habilidades necessárias ao alcance dos objetivos organizacionais.

O mundo do trabalho está em constante mudança e os profissionais para acompanhar estas mudanças deverão buscar o desenvolvimento pessoal e profissional.

O profissional está consciente da necessidade de aperfeiçoamento; está decidido sobre as mudanças profissionais que deseja fazer. É chegada a hora de implementar essas mudanças e, é chegada a hora de iniciar alguma ação efetiva de aprendizagem profissional, mas, como fazer isso?

Oliveira (1999) cita três diferentes trajetórias possíveis de serem utilizadas, dependendo das circunstâncias que cercam a situação: Freqüentar um curso de formação; seguir a orientação de um mentor (mentoring) ou montar um sistema autoditada.

Freqüentar um curso especializado é o meio mais lógico para se obter uma formação profissional. Com o diploma ou certificado, o profissional estará habilitado a exercer a sua atividade profissional.

Recentemente, a formação profissional por meios de cursos especializados tem sido afetada por outros problemas. Talvez o principal deles seja a acentuada aceleração do desenvolvimento tecnológico nas últimas décadas, o que acarreta a rápida defasagem dos conteúdos dos cursos em relação às demandas profissionais da sociedade.

Devido ao aumento e à sofisticação do conhecimento tecnológico, estima-se que a maioria dos cientistas está tecnicamente obsoleto dez anos após sua graduação numa escola técnica de nível superior. (BECKHARD, 1969). 
Sendo assim, a educação profissional, deve ser conduzida como um processo permanente, e não como uma etapa anterior e preparatória para a vida do trabalho. O profissional que não se preocupa em continuar estudando depois de formado, com certeza, se verá em bem pouco tempo, às voltas com seus problemas de obsoletismo profissional.

\subsubsection{MOTIVAÇÃO}

Toledo (1992) acredita que a motivação é um fator interno que dá início, dirige e integra o comportamento de uma pessoa. Esse motivo é constituído, usualmente, de um impulso e uma recompensa, que se dá quando o objetivo do impulso é alcançado. A motivação dos manipuladores é, sem dúvida, o principal fulcro em torno do qual deve girar a maior parte das atividades da gerência de produção.

Já para Umeda (1996), a motivação é necessária para que os manipuladores possam exercer a sua potencialidade no todo. Também cabe lembrar que a motivação transforma o clima organizacional em um clima de cooperação mútua. Dessa forma, a motivação torna-se também elemento essencial para se alcançar a qualidade, especialmente para alcançar a liberdade em qualidade, haja vista que os manipuladores, os quais vivem a realidade da organização, estarão aptos a decorrer sobre possíveis melhoria na organização.

No entanto, não é tão simples tratar da questão da motivação, tendo em vista que o que a gerência da organização pode fazer é criar condições para que cada um se motive, pois como já citado anteriormente, a motivação é algo 
que está dentro de cada um. Torna-se evidente a real necessidade do comprometimento do colaborador com a organização e também a desta com aquele 


\section{METODOLOGIA}

Esse estudo propõe-se a analisar o mercado e a possibilidade de criação de um centro de formação profissional: Centro Técnico de Treinamento em Confeitaria e Panificação.

Com base na classificação estabelecida por Vergara (2005), este estudo é definido como exploratório, descritivo e analítico. Exploratório, pois permite aprofundar o conhecimento sobre o tema do trabalho, isto é, a capacitação de mão-de-obra para a atividade de confeitaria. A pesquisa também é descritiva porque descreve as principais características da atividade confeiteira, particularmente sobre a qualificação da mão-de-obra e as modalidades de treinamento utilizadas nas empresas.

Quanto aos meios, a pesquisa foi bibliográfica, documental e de campo. Bibliográfica porque para a fundamentação teórico-metodológica do trabalho foi realizado um estudo sobre as origens da gastronomia, história do açúcar, história das confeitarias, treinamento e desenvolvimento e motivação, utilizando os meios que são acessíveis como livros, revistas, jornais, redes e Internet.

A pesquisa foi documental, pois colheu informações oficiais de instituições reguladoras como sindicatos e de campo pois foram visitados estabelecimentos comerciais que produzem e comercializam e assim obtevese uma visão de diferentes ângulos sobre um mesmo tema.

O questionário semi-estruturado teve como base as seguintes perguntas:

1. Quantas empresas estão cadastradas na entidade?

2. Quantas empresas estão cadastradas no ramo de confeitaria e panificação? 
3. A entidade oferece algum tipo de treinamento às empresas associadas?

Esse questionário foi aplicado aos presidentes e/ou responsáveis pelas entidades do Sindicato das Indústrias de Alimentação de Brasília (SIAB), do Instituto Euvaldo Lodi (IEL), o Sindicato dos Trabalhadores das Indústrias de Brasília (STIAB), o Sindicato dos Hotéis, Bares, Restaurantes e Similares de Brasília (SINDHOBAR), o Sindicato dos Empregados no Comércio Hoteleiro, Restaurantes Bares e Similares do Distrito Federal. O período de visita para obtenção dos dados foi durante os meses de fevereiro e março de 2006.

Também foram visitados alguns estabelecimentos no comércio de padarias e confeitarias, entre eles Rappel, Confeitaria Di Lorenzzo e Chez Le Petit.

A Junta Comercial do Distrito Federal também foi visitada com objetivo de confirmar dados. Porém não houve nenhuma resposta que pudesse agregar informação a essa pesquisa.

Com base nos dados obtidos foi feita uma análise, no sentido de levantar o número de empresas existentes no Distrito Federal na área de padaria e confeitaria, o nível de qualificação da mão-de-obra, a demanda de mercado por profissionais qualificados e a oferta de cursos de formação profissional para padeiro e confeiteiro.

Também foi realizada uma visita de campo às escolas SENAI e SENAC. A visita às instalações das instituições permitiu uma visão abrangente que confere o caráter de acompanhamento e levantamento de cenário do ramo. 
Durante as visitas foram levantados a estrutura curricular e valor de investimento dos cursos oferecidos.

Posteriormente, foi realizado um estudo analítico da estrutura de uma escola na América do sul como referência "benchmark" para a montagem do plano desse Centro de técnico de Treinamento em Confeitaria Padaria.

Não foram encontradas publicações cientificas na área de padaria e confeitaria, restando como alternativa para elaboração do estudo a utilização de revistas do setor, dados da Internet elaborados pelas entidades representantes do setor. 


\section{ANÁLISE MERCADOLÓGICA DO RAMO DE CONFEITARIA E PANIFICAÇÃO}

O ramo de confeitaria e panificação faz parte do grande segmento da gastronomia. Estes estabelecimentos estão entre os mais dinâmicos desse nicho no Distrito Federal e, também, entre os mais carentes de profissionais capacitados (SEBRAE, 2004).

Diante desta constatação, é inevitável a preocupação com a formação de novos profissionais, capacitados a participarem desse exigente mercado.

A riqueza cultural, os vários paladares e as diferentes tradições da população acabaram transformando Brasília em um dos pólos gastronômicos mais respeitados do país. Esse exigente mercado adveio da migração de população das diversas regiões do país para o Distrito Federal, trazendo consigo seus costumes locais e demandando, assim, uma infinidade de sabores singulares. (Tabela 2).

Tabela 2: Naturalidade da população segundo as Grandes Regiões, Distrito Federal e Entorno, 2004.

\begin{tabular}{|l|r|r|}
\hline \multicolumn{1}{|c|}{ Regiões Brasileiras e exterior } & \multicolumn{1}{c|}{ População } & \multicolumn{1}{c|}{$\%$} \\
\hline Distrito Federal & 1.006 .689 & 48 \\
\hline Região Nordeste & 558.792 & 26,7 \\
\hline Região Sudeste & 287.383 & 13,7 \\
\hline Região Centro-este & 136.791 & 6,5 \\
\hline Região Norte & 45.519 & 2,1 \\
\hline Região Sul & 30.388 & 1,4 \\
\hline Entorno & 26.831 & 1,3 \\
\hline Exterior & 6.142 & 0,3 \\
\hline Total & 2.098 .535 & 100 \\
\hline
\end{tabular}

Fonte: SEPLAN/ CODEPLAN - Pesquisa Distrital por Amostra de Domicílios. 2004.

Outras particularidades influenciam a gastronomia local, como a presença de um grande número de estrangeiros na cidade, ocasionada pela 
sua condição de capital do país, sede de órgãos e representações internacionais (como embaixadas, por exemplo), ou mesmo pelos atrativos turísticos de uma localidade considerada pela Organização das Nações Unidas para a Educação, a Ciência e a Cultura (UNESCO) como Patrimônio Cultural da Humanidade desde 1987.

A presença de estabelecimentos do ramo gastronômico em Brasília é maciça. Somente no Plano Piloto, são cerca de 300 empresas, distribuídas entre bares, restaurantes, cafés, pizzarias, confeitarias, creperias e "fast food".

Em todo o Distrito Federal, estima-se que esses números atinjam sete mil empresas ${ }^{7}$. O mercado é crescente, com público exigente, de paladar sofisticado e grande poder aquisitivo.

\subsection{Dimensão do Setor de Confeitaria e Panificação}

Segundo a Associação Brasileira da Indústria de Panificação e Confeitaria (ABIP), o país possui aproximadamente 52 mil empresas atuando nesse ramo. Os números do setor são bastante significativos, como se pode observar:

- 105 mil empresários;

- Atendimento de 40 milhões de cliente / dia;

- Faturamento de R\$25 bilhões por ano;

- Está entre os seis maiores segmentos industriais do país;

- Gera 580 mil empregos diretos (somente na produção, são 210 mil) e cerca de 1,5 milhão de indiretos;

- Remuneração média de $\mathrm{R} \$ 458,00$ /mês no setor;

\footnotetext{
${ }^{7}$ Dados coletados do site http://www.brasiliaconvention.com.br
} 
- Participa com 36,2\% das empresas da indústria de produtos alimentares e 7\% da indústria de transformação.

Apesar da grandiosidade dos números, o setor de confeitaria e panificação sofre também grande influência da seleção mercadológica natural. Somente os empresários mais competentes e preparados usufruem boas condições econômico-financeiras, restando aos demais apenas as margens desse gigante mercado consumidor.

No Distrito Federal, não há números claros sobre o tamanho do setor. O Sindicato das Indústrias de Alimentação de Brasília (SIAB), entidade patronal, declara possuir em seus quadros 230 associados, porém, a adesão dos empresários do setor é facultativa.

Para o Instituto Euvaldo Lodi (IEL), que tem foco na capacitação empresarial, aperfeiçoamento da gestão e elaboração de pesquisas para os diversos setores da indústria, em levantamento setorial realizado em junho 2003, apresentou o registro de 193 empresas, porém sua metodologia utiliza dados cedidos pela SIAB.

O Sindicato dos Trabalhadores nas Indústrias de Alimentação de Brasília (STAB), afirma possuir cadastradas 803 empresas. A julgar pela metodologia utilizada para apuração desses números, nenhum deles é adequado para mensuração do mercado do DF. (Tabela 3). 
Tabela 3: Número de estabelecimentos do setor de Panificação e Confeitaria

\begin{tabular}{|l|l|l|l|}
\hline INSTITUIÇÃo & $\begin{array}{l}\text { Instituto Euvaldo } \\
\text { Lodi (IEL) }\end{array}$ & $\begin{array}{l}\text { Sindic. das Indústrias de } \\
\text { Alimentação de Brasília } \\
\text { (SIAB) }\end{array}$ & $\begin{array}{l}\text { Sindic.dos } \\
\text { Trabalhadores nas } \\
\text { Indústrias de } \\
\text { Alimentação de } \\
\text { Brasília (STIAB) }\end{array}$ \\
\hline $\begin{array}{l}\text { Associados na } \\
\text { área de } \\
\text { Panificação } \\
\text { e Confeitaria }\end{array}$ & 193 empresas & 230 empresas & 803 empresas \\
\hline $\begin{array}{l}\text { Total de } \\
\text { associados } \\
\text { da Instituição }\end{array}$ & $\begin{array}{l}618 \text { empresas } \\
\text { cadastradas }\end{array}$ & $\begin{array}{l}\text { 230 empresas } \\
\text { cadastradas }\end{array}$ & $\begin{array}{l}1.200 \text { empresas } \\
\text { cadastradas }\end{array}$ \\
\hline $\begin{array}{l}\text { Último } \\
\text { cadastramento } \\
\text { de associados }\end{array}$ & Julho de 2003 & Dado não fornecido & Fevereiro de 2005 \\
\hline
\end{tabular}

Fonte: Compilação do autor.

Quanto ao número de anunciantes de produtos de padaria e confeitaria, são mais de 450 estabelecimentos (Mídia Telecon e Telelistas) somente no Plano Piloto. Apesar das divergências sobre o tamanho dessa indústria, podese concluir por meio de outros dados secundários que o mercado local oferta uma grande quantidade de vagas nesse setor. Esse fato, de antemão, constitui um excelente incentivo para novos candidatos a emprego e também para a qualificação dos que já fazem parte dele, à medida que a concorrência se acirre e as empresas elevem o grau de exigência para esses cargos.

\subsection{Panorama Econômico-Financeiro das Empresas}

O setor de confeitaria e panificação é constituído, em sua maior parcela, por micro e pequenas empresas. A ABIP possui acesso a levantamentos efetuados pela PROPAN que transmitem informações importantes sobre o perfil das empresas e do negócio em si. 
Pode-se observar no Gráfico 1, que a maior parte das empresas $(32,4 \%)$ têm faturamento até $\mathrm{R} \$ 56.000,00$ confirmando sua vocação de pequena empresa.

Gráfico 1: Faturamento anual das empresas do setor

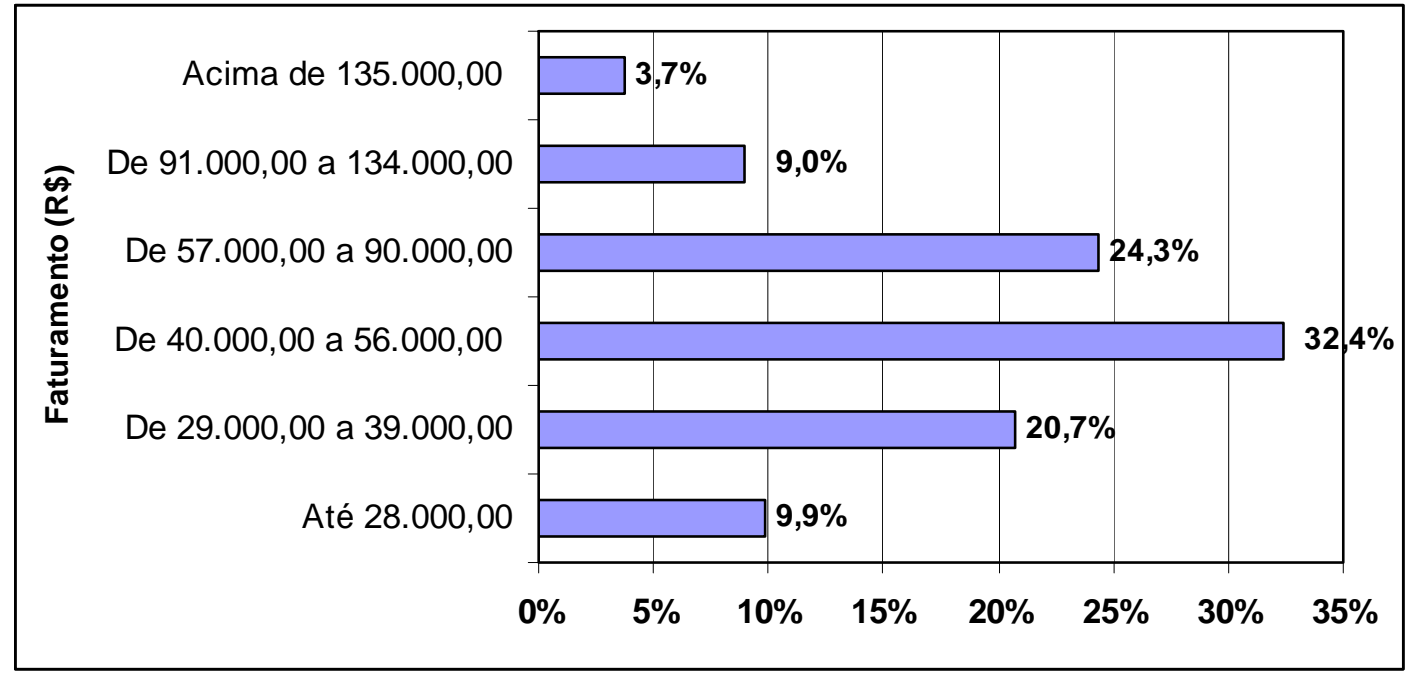

Fonte: www.abip.org.br

O gráfico 2 mostra que o item mais importante na composição da receita de um estabelecimento de confeitaria/padaria é a produção com 45\%, seguida de mercearia com 13\% e em terceiro lugar de importância laticínio com 10\%. Pode-se concluir a partir desses dados a relevância dos colaboradores responsáveis pela produção, pois a qualidade da produção é diretamente proporcional ao grau de qualificação dos colaboradores, portanto se o profissional é qualificado a produção será de boa qualidade, fato que pode garantir a venda e a continuidade do negócio. 
Gráfico 2: Composição Média da receita das Padarias / Confeitarias

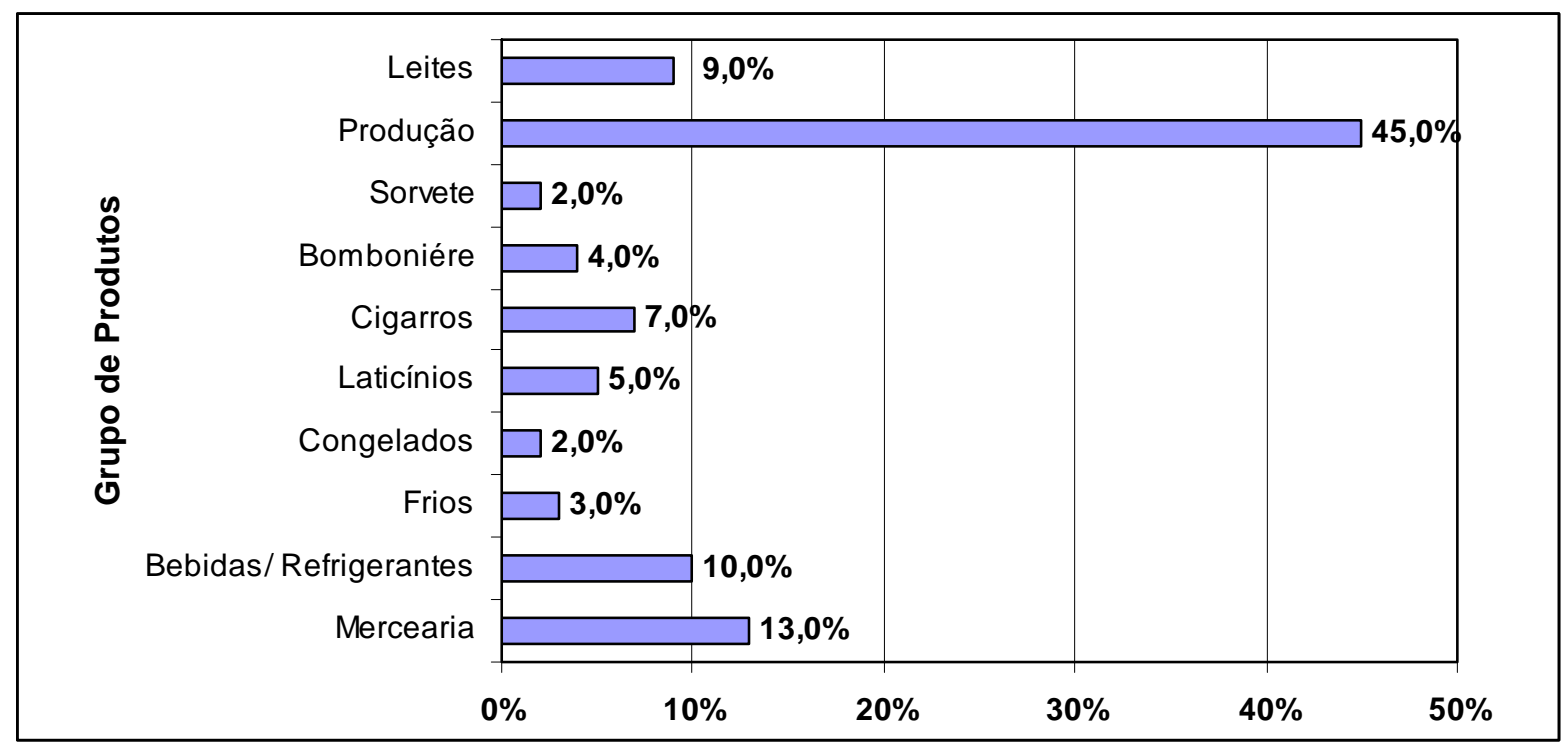

Fonte: www.abip.org.br

O gráfico 3 mostra que o item mais importante na composição dos custos dos estabelecimentos de confeitaria/padaria é a folha de pagamento com $33,84 \%$, seguida da matéria prima com $27 \%$ e em terceiro lugar os impostos com 15,38\%. Pode-se concluir a partir desses dados a importância dos colaboradores, pois o maior custo da empresa é com eles, que são responsáveis pela produção, maior fonte de receita da empresa. Fica evidente o quanto as empresas dependem de seus colaboradores que podem ser um fator crítico para o sucesso ou fracasso do negócio. Conclui-se assim a importância de se estar continuamente treinando os profissionais para garantir a continuidade e desenvolvimento do negócio.

Outros números relevantes encontrados na pesquisa feita pelo Programa de Apoio à Panificação (PROPAN):

-Salário médio por funcionário (Brasil): R\$ 458,00 (fora encargos);

-Salário médio por funcionários (São Paulo / SP): R\$ 620,00 (fora encargos). 
-A média é de 12 funcionários por empresa ${ }^{8}$.

Gráfico 3: Alocação dos custos das Padarias / Confeitarias

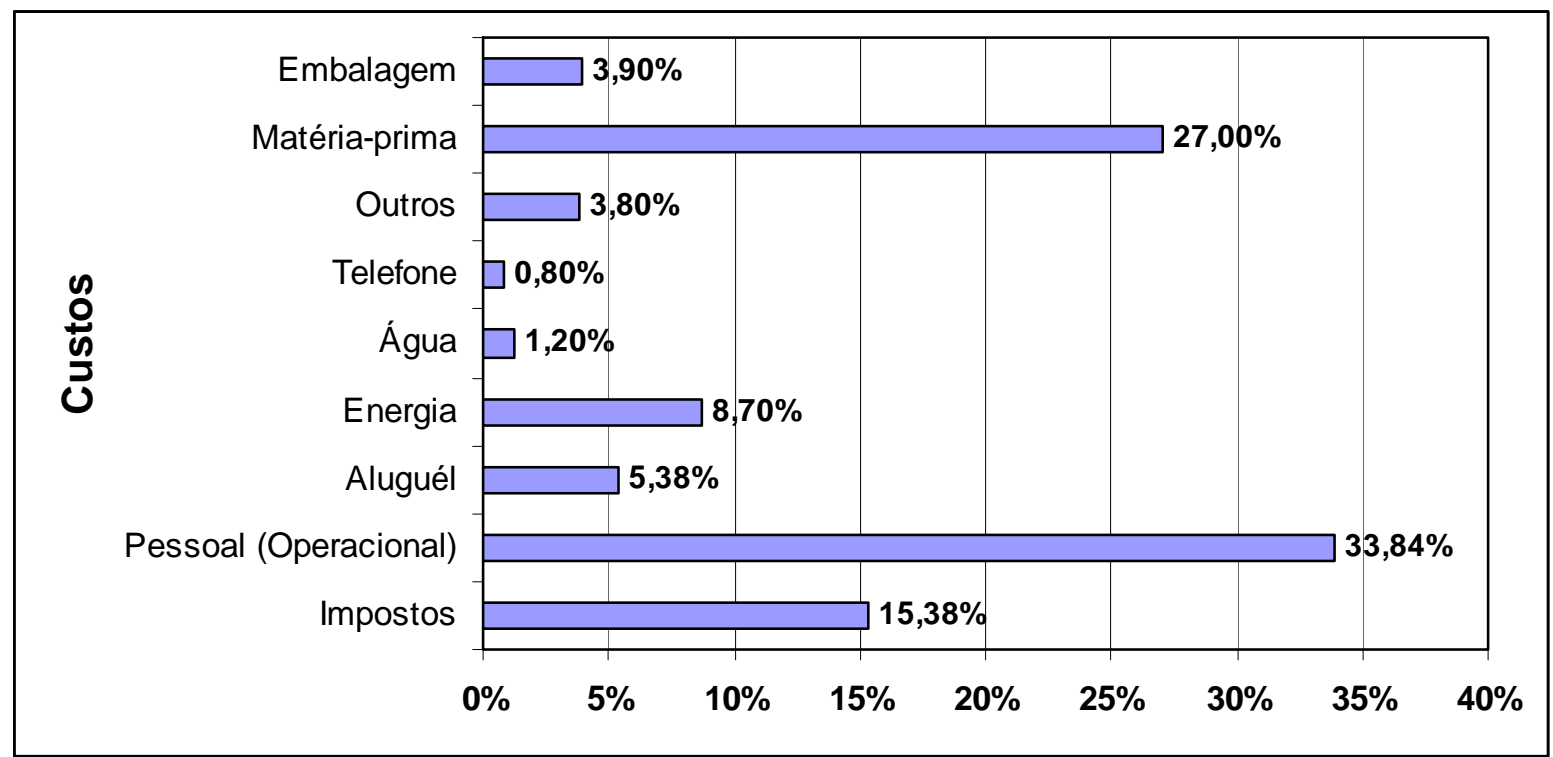

Fonte: www.abip.org.br

\subsection{Evolução e Tendências dos Estabelecimentos de}

\section{Confeitaria e Panificação}

Por muitos anos, o modelo de negócio predominante foi o das padarias tradicionais, concentradas na fabricação de uma pequena variedade de produtos que utilizam o trigo como insumo. A compra era efetivada no balcão, diretamente com um atendente. Porém, nos dias atuais, esse comércio vem perdendo espaço para estabelecimentos mais sofisticados, que oferecem uma gama enorme de produtos para o cliente.

Oferecendo uma infinidade de tipos de bolos, doces, massas e pães, disposição estratégica dos produtos (ao alcance dos olhos e das mãos do

\footnotetext{
${ }^{8}$ Pesquisa realizada com 680 empresas da Grande Belo Horizonte / MG. A média das padarias participantes do PROPAN é de 17,1 funcionários / empresa.
} 
consumidor, sem prejuízos em questões de higiene), o novo modelo de negócio vem despertando uma elevação na demanda. Com ticket médio (valor médio da compra) muito superior aos das antigas padarias, as "butiques" já são um excelente negócio para os empresários que, há alguns anos atrás, identificaram esse modelo como uma tendência futura para o mercado.

Atualmente, os tipos de estabelecimento desse nicho podem ser classificados da seguinte forma:

- Padaria tipo Butique: localizadas em regiões com alto poder aquisitivo, concentradas em produtos próprios e importados. Sua quantidade não é representativa;

- Padaria de Serviço: localizadas em regiões centrais e ruas com grande circulação e concentração de lojas comerciais ou escritórios. Além dos produtos de padaria, confeitaria e "rotisserie" oferecem serviços de bar, lanchonete, "fast food", entre outros;

- Padaria de Conveniência: localizadas em bairros residenciais. Além dos produtos próprios de padaria, confeitaria, "rotisserie" e serviços bar e lanchonete, oferecem uma gama de produtos de conveniência, chegando algumas a oferecer cerca de 3.000 itens;

- Pontos quentes: tendência européia na qual a padaria abre uma filial e a abastece com alguns produtos embalados e congelados (ou resfriados), os quais são enfornados no ponto de venda. Assim, não necessita de grandes espaços para fabricação ou armazenagem, visto que o abastecimento de produtos é diário ${ }^{9}$.

\footnotetext{
${ }^{9}$ Informações coletadas no site <http://www.abip.org.br>. Acesso em fev., 2006.
} 


\subsection{Perfil e Preferências dos Consumidores}

O mundo atual pede o consumo de produtos mais saudáveis. Os consumidores modernos querem muita informação. Todos estão cada vez mais preocupados com a qualidade nutricional dos alimentos que consomem e levam para as suas famílias. Além disso, os requintes da gastronomia estão cada vez mais ganhando espaço no gosto dos indivíduos.

O grande acesso a uma vasta gama de novos ingredientes, a popularização de verdadeiros tesouros da natureza para o paladar e a criatividade na combinação de ingredientes vem transformando as preferências do consumidor.

Pesquisas mostram, também, que outros fatores "tradicionais" para o ramo continuam fazendo bastante diferença no momento de definição do local de compra. A tabela 4 mostra as opções mais votadas pelos consumidores, classificadas em ordem de importância, em pesquisa para levantamento dos motivos para efetuar compras em padarias.

Tabela 4: Ranking de motivos para se consumir em padarias

\begin{tabular}{clc}
\hline Classificação & Variável perguntada & Percentual \\
\hline $1^{\circ}$ & É próximo da residência & $100,00 \%$ \\
\hline $2^{\circ}$ & É próximo do local de Trabalho & $52,70 \%$ \\
\hline $3^{\circ}$ & Condições de higiene e limpeza & $30,70 \%$ \\
\hline $4^{\circ}$ & Cortesia no atendimento & $28,80 \%$ \\
\hline $5^{\circ}$ & Qualidade dos produtos & $25,70 \%$ \\
\hline $6^{\circ}$ & Variedade de pães e doces & $18,60 \%$ \\
\hline $7^{\circ}$ & Rapidez no atendimento & $14,30 \%$ \\
\hline
\end{tabular}




\begin{tabular}{clc}
\hline $8^{\circ}$ & Pão quente a toda hora & $11,30 \%$ \\
\hline $9^{\circ}$ & Instalações e ambiente agradáveis & $6,50 \%$ \\
\hline $10^{\circ}$ & Preço mais acessível & $5,60 \%$ \\
\hline $11^{\circ}$ & Horário de funcionamento & $4,70 \%$ \\
\hline $12^{\circ}$ & Algum morador da casa definiu & $2,90 \%$ \\
\hline $13^{\circ}$ & Praticidade no sistema de caixa & $2,00 \%$ \\
\hline $14^{\circ}$ & Por ter estacionamento & $1,80 \%$
\end{tabular}

Fonte: Um panorama do segmento de padarias no Brasil. BNDES, 2001. In: <http://www.bndes.gov.br/conhecimento/setorial/get4is26.pdf> $>$.Acesso em mar., 2006.

\subsection{Panorama do Setor no Distrito Federal}

As empresas dos ramos de panificação e confeitaria do Distrito Federal encontram-se em processo de modernização e desenvolvimento. Os empresários do setor, cientes da necessidade de reestruturação de seus negócios, buscam instituir diversas melhorias em suas empresas.

O cuidado com o atendimento é uma das grandes preocupações do empresariado, a fim de que possa atender as novas demandas do exigente público consumidor.

Seguindo as tendências, vários estabelecimentos vêm executando alterações no seu modelo de negócio e na maneira de comercialização. A estrutura física também é alvo dessa tendência, à medida que "layouts" são modificados para comportar espaço para bate-papo e encontro de amigos, onde, claro, os produtos do estabelecimento estão sempre presentes. Outro sinal do importante papel do remodelamento para as empresas desse ramo é a maior quantidade de vitrines expositoras, que levam o produto para perto do cliente. 
O perfil profissional dos indivíduos que atuam nesse setor deixa bastante a desejar. Na maioria dos casos, o processo de formação profissional é informal, com baixo conhecimento técnico. Essa realidade é constatada tanto na área de produção quanto na de atendimento. O mercado de trabalho não possui profissionais preparados para atender este novo mercado.

Apesar desta constatação, o processo de qualificação desses profissionais torna-se um problema para o setor. Mesmo reconhecendo a importância do treinamento, ainda são poucas as empresas que deslocam seus funcionários para participarem de programas de qualificação e reciclagem.

De outro lado, poucos são aqueles profissionais que procuram adequarse às novas necessidades do mercado de trabalho. O custo desses programas quase sempre é a maior barreira para ambos.

\subsection{Instituições Responsáveis pelo Desenvolvimento do Ramo de Panificação}

Existem várias instituições atuantes na busca da modernização e desenvolvimento de vários ramos ligados à gastronomia. Todos eles têm papel fundamental para o crescimento e reconhecimento dessa indústria tão importante no nosso país e, também, a valorização dos nossos profissionais perante o mercado mundial. Dessas, destacam-se: 
- ABRESI: Associação Brasileira de Gastronomia, Hospitalidade e Turismo.

A ABRESI representa um importante marco na história do Turismo no país. Com sua criação, os setores de Gastronomia, Hospedagem e Turismo passaram a contar com uma entidade que vem se impondo, por seu dinamismo, na condução de projetos e ações vinculados ao seu compromisso de participar do desenvolvimento da indústria do turismo no país. A entidade se mantém presente nas principais iniciativas do setor, em âmbito nacional e internacional, e desenvolve atividades que colaboram com o crescimento do Turismo como atividade econômica, dotado de melhor infra-estrutura e serviços de padrão internacional.

Entidades como a Confraria Gastronômica do Brasil e o Instituto Tecnológico de Gastronomia e Nutrição do Brasil foram criadas pela ABRESI, para pesquisa e desenvolvimento da cultura e educação alimentícia, e são conveniadas com a Universidade de Bologna, a mais antiga Universidade especializada na pesquisa de insumos alimentares.

Dentre as suas principais realizações, em favor da valorização da gastronomia brasileira, destaca-se a outorga à cidade de São Paulo, do título de "Capital Mundial da Gastronomia", com o apoio de 43 nações e diversas instituições internacionais, e o título de Vice-Campeã Mundial de Pastelaria Fina, concedido ao Brasil no Campeonato Mundial organizado pela Union Euro Americana de Artesanos Del Dulce ${ }^{10}$.

\footnotetext{
${ }^{10}$ Informações coletadas no site <http://www.abresi.com.br>.
} 
- ABIA: Associação Brasileira das Indústrias da Alimentação

A ABIA é uma instituição que presta serviços às empresas do setor de alimentação desde 1963. Ela é referência para contatos entre o poder público e os industriais, sempre prestigiada pelas autoridades por sua credibilidade. A ABIA é freqüentemente consultada para prover o governo com números da indústria. Os órgãos de saúde pública recorrem continuamente aos serviços que seu Departamento Técnico presta. Desde 1964 foi declarada Órgão Técnico e Consultivo do Poder Público.

O mais importante é que a indústria confia na intermediação da ABIA em seu relacionamento institucional com o consumidor, os demais setores econômicos e o governo. Além disso, é disponibilizado diariamente por e-mail "A Indústria de Alimentos em Destaque", boletim contendo resumo das principais notícias do dia.

A ABIA tem dinâmica atuação política junto aos escalões superiores do governo e do legislativo, buscando antecipar soluções para os problemas potenciais da indústria de alimentos. A ABIA tem mecanismos internos para comunicar-se com a própria indústria, de forma a detectar cedo as necessidades das empresas: há diversos Setores, constituídos por grupos de empresas de um mesmo ramo, que discutem periodicamente e encaminham seus problemas, há Comissões, que são órgãos permanentes e há Comitês, criados para solucionar questões novas que surgem, nos quais especialistas podem discutir com seus colegas de outras empresas, propor ações à Associação e orientar suas empresas sobre questões relevantes ${ }^{11}$. (www.abia.org.br)

\footnotetext{
${ }^{11}$ Para maiores informações consultar o site<http://www.abip.org.br>
} 
- ABIP: Associação Brasileira da Indústria da Panificação e Confeitaria

A ABIP representa através das entidades filiadas quase $70 \%$ da panificação Brasileira, são Associações e Sindicatos Patronais, além de Associações Estaduais e Institutos de Panificação.

A Associação tem por finalidade a coordenação e defesa da classe dos industriais da panificação e confeitaria constituídos em todo o território nacional, e o intuito de colaboração com os Poderes Públicos e as demais Associações, no sentido de solidariedade social.

A Associação goza das mais ampla e total liberdade e autonomia, não se sujeitando a qualquer tipo de intervenção privada ou governamental, admitindo apenas o pronunciamento do Poder Judiciário, quanto à legalidade dos seus atos, que, por serem "atos interna corporis", não admitem manifestação quanto ao seu mérito, sua oportunidade e conveniência ${ }^{12}$.

\section{- PROPAN: Programa de Apoio à Panificação}

A Associação Brasileira da Indústria de Panificação e Confeitaria (ABIP), e a Associação Brasileira da Industria de Trigo (ABITRIGO) são as entidades idealizadoras e coordenadoras do PROPAN. Cabe a elas conceder o "Certificado de Qualificação" às panificadoras integrantes do programa, bem como organizar dados sobre o desempenho do setor de panificação.

O Instituto Tecnológico da Panificação e Confeitaria (ITPC) é a entidade executora que realiza os treinamentos e consultorias das panificadoras, através dos consultores credenciados.

\footnotetext{
${ }^{12}$ Consultar o site<http://www.abip.org.br>
} 
O PROPAN estabeleceu algumas metas a serem cumpridas a médio e longo prazo. Uma delas é capacitar 10 mil panificadoras em todo o país. Pretende, também, aumentar a lucratividade e competitividade de toda cadeia produtiva do trigo.

Oferece, também, informações e orientações aos empresários, de modo a aperfeiçoar e tornar mais eficaz a administração de panificadoras. Entre os tópicos abordados no programa estão: forma mais eficiente de eliminar desperdícios, como padronizar os processos produtivos, melhoria na qualidade do atendimento, gestão de pessoas, gerenciamento de produção e otimização de vendas.

Para dar uma nova visão das panificadoras frente ao público, o PROPAN oferece Certificados de Qualidade, de acordo com o grau de otimização por elas atingidas.

O processo operacional de treinamento dos consultores atuantes juntos ao programa é realizado pela Márcio Rodrigues \& Associados, que detém a tecnologia aplicada nos treinamentos e consultorias, através do ITPC ${ }^{13}$.

\section{- SIAB: Sindicato das Indústrias de Alimentação de Brasília}

O SIAB é uma sociedade civil de direito privado, de intuitos não econômicos e duração ilimitada, fundado em 27 de dezembro de 1971. O quadro associativo efetivo composto de 174 empresas filiadas. Os objetivos são:

- Representar legalmente a categoria perante as autoridades administrativas e judiciárias;

\footnotetext{
${ }^{13}$ Consultar o site<http://www.propan.com.br>
} 
- Promover a defesa, em juízo, dos interesses individuais ou coletivos de suas empresas associadas;

- Celebrar Convenções Coletivas de Trabalho; Demandar em dissídios coletivos de trabalho;

- Eleger ou designar os representantes da categoria nas entidades congêneres ou hierárquicas superiores e de âmbito nacional;

- Colaborar com os poderes constituídos, no estudo e solução dos problemas relacionados com a categoria ${ }^{14}$.

\subsection{Empresas Concorrentes na Capacitação de Profissionais}

Ainda são poucas as empresas, no Distrito Federal, que oferecem cursos de capacitação técnica no setor de confeitaria e panificação. Abaixo estão citadas as de maior representatividade no atendimento dessa demanda:

- SENACI DF: Serviço Nacional de Aprendizagem Comercial do Distrito Federal

O SENAC é uma organização de caráter privado com a missão de contribuir para a superação dos problemas sociais e econômicos do país, por meio da educação profissional de trabalhadores para as áreas de comércio de bens e serviços ${ }^{15}$. (www.senac.br)

A tabela 5 compila os cursos oferecidos pela intuição. Segundo declaração dos entrevistados proprietários das empresas do ramo de confeitaria e padaria as pessoas que freqüentam esses cursos, normalmente não têm experiência profissional e estão em busca de um lugar no mercado de

\footnotetext{
${ }^{14}$ Para maiores esclarecimentos consultar <http:// www.siab.org.br >

${ }^{15}$ Informações pelo endereço <http://www.senac.br>
} 
trabalho, primeiro emprego e donas de casa que já atuam produzindo em sua residência e que buscam o aprimoramento de técnicas por meio destes cursos.

Portanto pode-se inferir que o nível dos cursos é elementar, não podendo ser considerado opção para qualificação profissional conforme exigência do mercado.

Tabela 5: Oferta dos cursos na área de panificação, confeitaria e salgados.

\begin{tabular}{|c|c|c|c|}
\hline CURSO & CONFEITEIRO & PADEIRO & SALGADEIRO \\
\hline PERÍODO & 90 horas & 120 horas & 60 horas \\
\hline DIAS & de $2^{a}$ a $6^{a}$ feira & de $2^{a}$ a $6^{a}$ feira & de $2^{a}$ a $6^{a}$ feira \\
\hline $\begin{array}{l}\text { TRABALHO } \\
\text { PRÁTICO }\end{array}$ & $\begin{array}{l}\text { Massas: massa } \\
\text { básica para bolos } \\
\text { confeitados/ pão-de- } \\
\text { ló/ bolos comuns } \\
\text { Coberturas: chantilly/ } \\
\text { marshmallow, pasta } \\
\text { americana } \\
\text { Recheios: cremes } \\
\text { comuns, francês, } \\
\text { baunilha } \\
\text {-Bombons e biscoitos }\end{array}$ & $\begin{array}{l}\text { Todos os tipos de pães: } \\
\text { pão de as, pão francês, } \\
\text { pão Brasil, pão de queijo } \\
\text { e outros } \\
\text { Biscoitos }\end{array}$ & $\begin{array}{l}\text { Todos os } \\
\text { salgados: } \\
\text { Coxinha, Risole } \\
\text { Quibe, Empada, } \\
\text { croquete }\end{array}$ \\
\hline $\begin{array}{l}\text { ASSUNTO } \\
\text { TÉCNICO }\end{array}$ & $\begin{array}{l}\text { Noções de higiene e } \\
\text { de segurança } \\
\text { alimentar }\end{array}$ & $\begin{array}{l}\text { Noções de higiene e de } \\
\text { segurança alimentar }\end{array}$ & $\begin{array}{l}\text { Noções de higiene } \\
\text { e de segurança } \\
\text { alimentar }\end{array}$ \\
\hline $\begin{array}{l}\text { INVESTI- } \\
\text { MENTO }\end{array}$ & $\begin{array}{l}\mathrm{R} \$ 470,00 \text { em até } 3 \\
\text { parcelas }\end{array}$ & $\begin{array}{l}\mathrm{R} \$ 572,00 \text { em até } 4 \\
\text { parcelas }\end{array}$ & $\begin{array}{l}\text { Dado não } \\
\text { fornecido }\end{array}$ \\
\hline
\end{tabular}

Fonte: Senac / DF, 2006 
- SENAI / DF: Serviço Nacional de Aprendizagem Industrial do Distrito Federal

O SENAI possui a missão de contribuir para o fortalecimento da indústria e o desenvolvimento pleno e sustentável do país, promovendo a educação para o trabalho e a cidadania, a assistência técnica e tecnológica, a produção e disseminação de informação e a adequação, geração e difusão de tecnologia ${ }^{16}$.

Segundo reportagens e informações do SIAB, as empresas associadas ao PROPAN, e ao próprio SIAB juntamente com o Senai estão montando um curso chamado de "Panifieiro", acessível somente para profissionais. O curso terá uma estrutura curricular multidisciplinar passando por disciplinas como higiene e chegando até noções básicas de gestão de negócios, conforme tabela 6. O Senai BH e Joinville já concluíram turmas do curso de Panifieiro, e estarão montando novas turmas para o primeiro semestre de 2006. No entanto, mesmo tendo solicitado informações sobre a estrutura curricular do curso por diversas vezes junto ao Senai BH e Joinville, não se obteve resposta.

Tabela 6: Oferta dos cursos de qualificação e aperfeiçoamento na área de panificação, confeitaria e salgados.

\begin{tabular}{|l|c|c|c|}
\hline CURSo & $\begin{array}{l}\text { Confeiteiro de } \\
\text { bolos, tortas, } \\
\text { folhados e } \\
\text { semifolhados. }\end{array}$ & $\begin{array}{l}\text { Padeiro, pão francês, pão doce } \\
\text { e derivado. }\end{array}$ & Panifieiro $^{17}$ \\
\hline PERÍODO & 100 horas & 140 horas & $\begin{array}{c}\text { Em } \\
\text { formação }\end{array}$ \\
\hline DIAS & de $2^{\mathrm{a}}$ a $6^{\mathrm{a}}$ feira & de $2^{\mathrm{a}}$ a $6^{\mathrm{a}}$ feira & $\begin{array}{c}\text { Em } \\
\text { formação }\end{array}$ \\
\hline
\end{tabular}

\footnotetext{
${ }^{16}$ Consultar <http://www.df.senai.br>

${ }^{17}$ O curso de Panifieiro segue a nomenclatura específica do Senai. O curso é somente para profissionais da área que trabalham nas empresas de panificação e confeitaria associadas ao Sindicato da Indústria de Panificação e Confeitaria e ao PROPAN. O curso é multidisciplinar com estrutura curricular que oferece disciplinas de técnica de produção, comportamento empreendedor, higiene, segurança alimentar e noções básicas de gestão de negócio.
} 


\begin{tabular}{|c|c|c|c|}
\hline $\begin{array}{l}\text { TRABALHO } \\
\text { PRÁTICO }\end{array}$ & 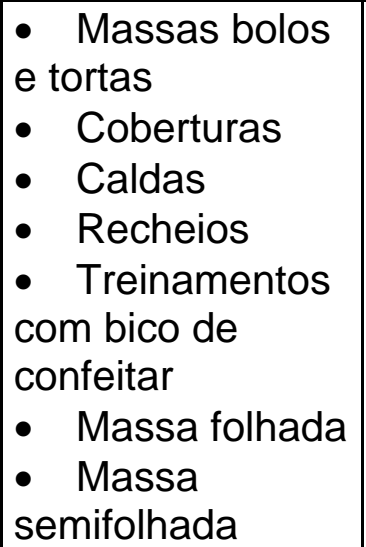 & $\begin{array}{l}\text { - Pão francês } \\
\text { - Pão bisnaga } \\
\text { - Pão baguette francesa } \\
\text { - Pão espiga } \\
\text { - Pão manteiga } \\
\text { - Pão flor de trigo } \\
\text { - Pão parafuso } \\
\text { - Rosquinha francesa } \\
\text { - Pão de mesa e pão canela } \\
\text { - Rosquinha e outros }\end{array}$ & $\begin{array}{c}\text { Em } \\
\text { formação }\end{array}$ \\
\hline $\begin{array}{l}\text { ASSUNTO } \\
\text { TÉCNICO }\end{array}$ & $\begin{array}{l}\text { Dado não } \\
\text { informado }\end{array}$ & $\begin{array}{l}\text { Regras gerais de higiene, } \\
\text { segurança no manuseio de } \\
\text { maquinários e utensílios, } \\
\text { ingredientes básicos e } \\
\text { fermentação, receituário e } \\
\text { balanceamento }\end{array}$ & $\begin{array}{c}\text { Em } \\
\text { formação }\end{array}$ \\
\hline INVESTIMENTO & \begin{tabular}{|l|}
$\mathrm{R} \$ 135,00$ em até \\
4 parcelas.
\end{tabular} & $\mathrm{R} \$ 115,00$ em até 6 parcelas & $\begin{array}{c}E m \\
\text { formação }\end{array}$ \\
\hline
\end{tabular}

Fonte: Senai/DF.

Durante as visitas ao SENAC e SENAI observou-se que as instalações são antigas, os equipamentos são obsoletos e os profissionais não dispõem de conhecimentos técnicos atualizados, portanto inadequados segundo as exigências atuais de mercado. A estrutura curricular dos cursos aborda somente as técnicas de produção tradicionais, formando profissionais limitados. Tais constatações justificam as queixas dos proprietários de confeitaria e padaria quanto ao despreparo dos profissionais disponíveis no mercado formados nestas instituições.

Existem algumas outras instituições que oferecem curso de formação e especialização no Distrito Federal. Entre essas, estão algumas escolas de culinária e lojas de artigos para festas que em geral só ofertam cursos de curta duração. Estas instituições não oferecem uma programação anual, atendem somente as demandas pontuais. Embora algumas dessas instituições possuam credibilidade no mercado que atuam, no entanto as capacitações por elas oferecidas não servem como modelo e tão pouco como referencial de mercado. 


\subsection{Benchmarking ${ }^{18}$ em Confeitaria na América Latina}

Para conhecer um pouco sobre algumas empresas que são referência no mercado de capacitação e aprimoramento de profissionais, sua experiência e suas boas práticas, as seguintes instituições foram contatadas:

O Instituto Argentino de Gastronomia (IAG) nasceu há alguns anos, quando um grupo de pessoas observou a necessidade de um acompanhamento para o setor turístico e hoteleiro da Argentina, principalmente em relação à padronização da escola gastronômica do país.Durante muito tempo, os chefes argentinos foram pessoas que viram a necessidade de buscar formação profissional no exterior, devido à inexistência de escolas que estivessem à altura de suas necessidades e expectativas.

O IAG tem como presidente um de seus fundadores, o Senhor Rolando Carvaja. A área técnica é liderada pelo chefe Ariel Rodrigues Palácios, acompanhado por professores de grande êxito profissional na arte culinária. Todo o corpo docente recebe capacitação constante nas melhores escolas profissionais do mundo.

Além das aulas teóricas, os alunos dispõem de uma ampla oficina totalmente equipada para a realização de práticas de culinárias, sempre orientada pelos professores. Esse modelo promoveu um salto qualitativo essencial para o ensino da arte culinária do país. A partir do sexto mês de estudos, os aspirantes a chefes já estão em condições de realizar tarefas profissionais com êxito.

\footnotetext{
${ }^{18}$ De acordo com o International Benchmarking Clearinghouse (IBC), o benchmarking é um processo sistemático e contínuo de medida e comparação das práticas de uma organização com as das líderes, ou referencia de qualidade, no sentido de obter informações que a possam ajudar a melhorar o seu nível de desempenho.
} 
O IAG conhece as necessidades do mercado e está a par das novas tendências, como utilização de novos ingredientes e técnicas. Os profissionais gastronômicos participam gratuitamente, todo ano, de seminários extras curriculares com chefes e estrelas nacionais e internacionais, que visitam freqüentemente o instituto.

Devido às constantes mudanças do mercado gastronômico, há necessidade de constante aperfeiçoamento da formação, tanto para os graduados quanto para os pós-graduados. O instituto é líder na Argentina na formação de profissionais, em inovação, qualidade e em quantidade de alunos graduados. Os instrutores foram formados com campeões mundiais e olímpicos de cozinha e confeitaria, e nas melhores escolas da França, China, Tailândia, Itália, Índia, Estados Unidos e Suíça e com práticas nos restaurantes de mais alto nível, como Paul Bocuse, Georges Blanc e Alain Ducasse ${ }^{19}$.

${ }^{19}$ Para maiores esclarecimentos consultar <http://www.artesculinarias.com.br> 


\section{PROPOSTA PARA CRIAÇÃO DO CENTRO TÉCNICO DE TREINAMENTO EM CONFEITARIA E PANIFICAÇÃO}

Baseado nos resultados da análise das necessidades identificadas na pesquisa que indica a existência de campo para empreender nesse ramo de capacitação, este projeto propõe a criação de um Centro de Treinamento na área de panificação e confeitaria.

\subsection{Objetivo do Centro Técnico de Treinamento}

O Centro Técnico de Treinamento tem como missão oferecer ao aluno informações técnicas e vivência na área ao aluno por meio de um método que se destaca pela construção contínua e coletiva do saber.

O Centro Técnico de Treinamento proporcionará um ambiente favorável à construção do conhecimento, onde o aluno desenvolverá competências e habilidade indispensáveis no processo de formação profissional.

E ainda proporcionará ao aprendiz conhecimento do perfil empreendedor e das técnicas específicas de higiene pessoal e de alimentos, segurança alimentar, estrutura nutricional, cultura alimentar, ética profissional, técnicas de preparo dos alimentos e noções básicas de gestão administrativa e financeira.

O conteúdo multidisciplinar contemplará as diversas áreas de conhecimento proporcionando ao aluno uma formação profissional ampla adaptada às exigências atuais de mercado.

\subsection{Público Alvo}

Inicialmente o Centro Técnico de Treinamento visa atender profissionais da área de panificação e confeitaria que já atuam precariamente no mercado, 
pois não dispõem do conhecimento necessário ao adequado desempenho de suas funções.

Em um segundo momento o Centro atenderá a comunidade como um todo: donas de casa, profissionais liberais em busca de entretenimento e outros, oferecendo uma grade de cursos voltada para formação técnica mais pontual que possa atender às necessidades e aos interesses do público amador que busca iniciar-se no ramo.

\subsection{Metodologia de Ensino do Centro Técnico de Treinamento}

Os cursos serão divididos em módulos que terão como base para construção do conhecimento o suporte de material, apostilas, aulas teóricas, seminários, aulas demonstrativas, aulas práticas nos laboratórios de panificação e confeitaria, exibição de vídeos, palestras com depoimento de profissionais de sucesso, visitas a empreendimentos do setor e estágio obrigatório.

\subsubsection{AULAS TEÓRICAS}

As aulas teóricas serão diárias (4 horas) de segunda a sexta feira nos turnos matutino, vespertino e noturno. O material didático será entregue no início do módulo. Serão utilizados os recursos materiais: quadro branco, televisão, DVD e Data Show.

\subsubsection{AULAS DEMONSTRATIVAS}

Os alunos estarão em uma sala de observação próxima ao laboratório de aulas práticas e poderão por meio de um espelho instalado no laboratório 
observar as imagens e avaliar o passo a passo da manipulação dos alimentos desde a higiene até a sua decoração. Esta aula necessita além do professor de laboratório um professor auxiliar na sala de observação para conduzir a adequada aprendizagem por meio da observação. Esta aula é uma eficiente ferramenta para o processo de aprendizagem.

\subsubsection{AULAS PRÁTICAS}

Durante as aulas práticas os estudantes realizarão algumas receitas já observadas e analisadas na aula demonstrativa, podendo assim aplicar as teorias e as técnicas aprendidas. As aulas práticas serão organizadas em pequenos grupos sendo o máximo de 20 alunos por laboratório. O laboratório possuirá os mais modernos equipamentos e utensílios disponíveis no mercado, que facilitarão o processo de aprendizagem.

Ao final de cada aula o professor comentará o desempenho do grupo no preparo dos alimentos e após a degustação da produção o grupo elaborará um relatório da aula.

\subsubsection{ESTÁGIO}

O Centro de Técnico de Treinamento buscará convênios com instituições públicas e privadas nas áreas de alimentação especificamente panificação e confeitaria; estes estágios serão supervisionados.

\subsubsection{A ESTRUTURA CURRICULAR DOS CURSOS}

O currículo proposto contempla as técnicas nas áreas de panificação e confeitaria, oferece disciplinas de cunho humanista para que o aluno possa 
vivenciar a construção do conhecimento sempre numa perspectiva ética. Oferece ainda disciplinas das áreas de higiene, nutrição, segurança alimentar e de noções básicas da gestão administrativa e financeira.

Os cursos oferecidos serão divididos em módulos:

- Comportamento Empreendedor;

- Higiene Pessoal e de Alimentos;

- Estrutura Nutricional;

- Cultura Alimentar;

- Ética Profissional;

- Técnicas de Panificação;

- Técnicas de Panificação Internacional;

- Técnicas de Confeitaria;

- Técnicas de Confeitaria Internacional;

- Gestão de Negócios.

\subsubsection{CORPO DOCENTE}

O corpo docente de um centro de treinamento e capacitação deverá ser formado por profissionais especializados com mais de 10 anos de experiência de mercado e com reconhecimento público de suas habilidades acadêmicas.

\subsection{Lay Out do Centro de Capacitação}

Cada ambiente do Centro Técnico de Treinamento em Confeitaria e Panificação foi elaborado levando em conta o fluxo operacional das atividades propostas para o local. (Figuras 1,2,3,4 e 5). 
Figura 1: Planta Baixa do Centro Técnico de Treinamento

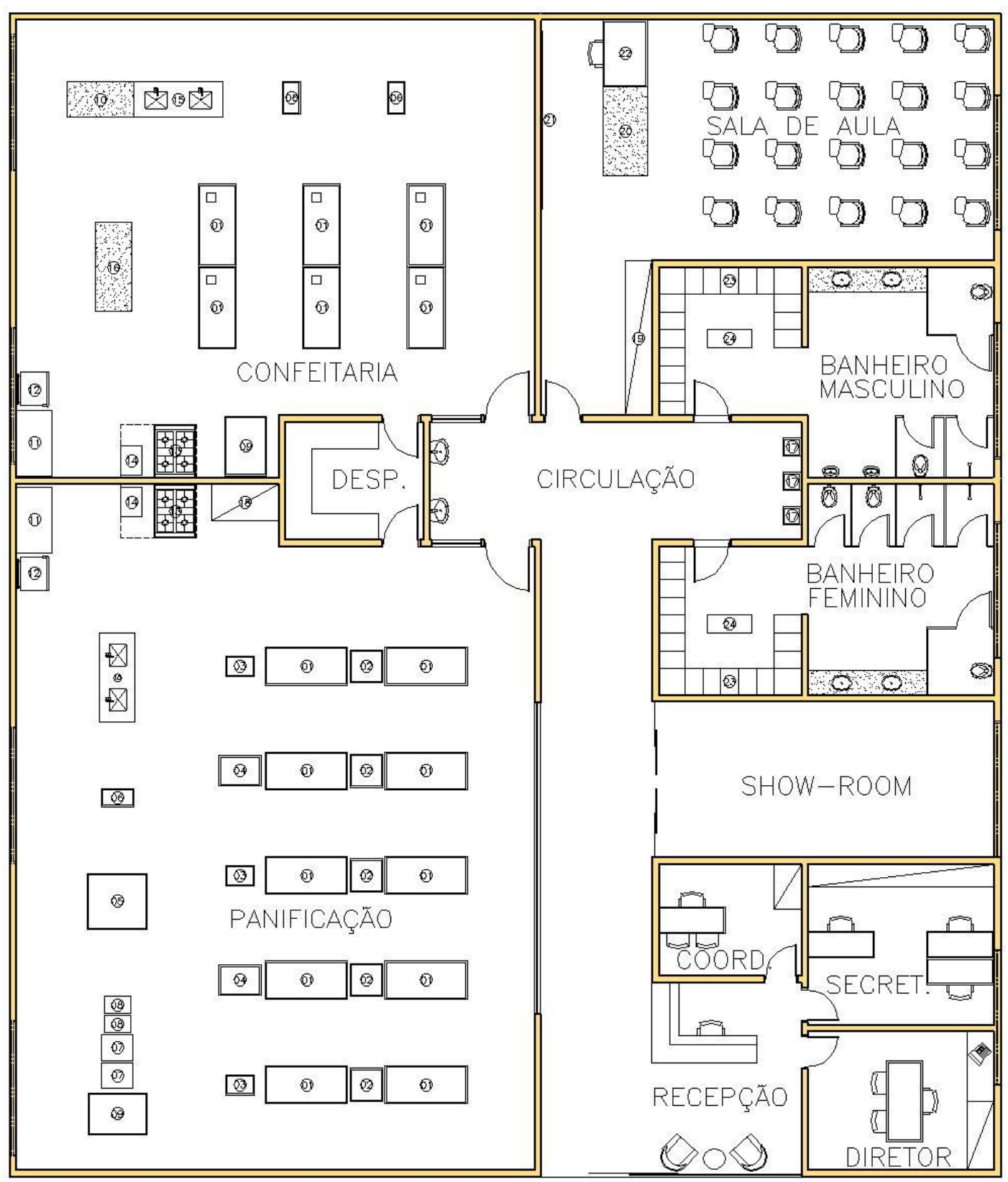

PLANTA BAIXA 
Figura 2: Medidas dos Laboratórios de Panificação e Confeitaria

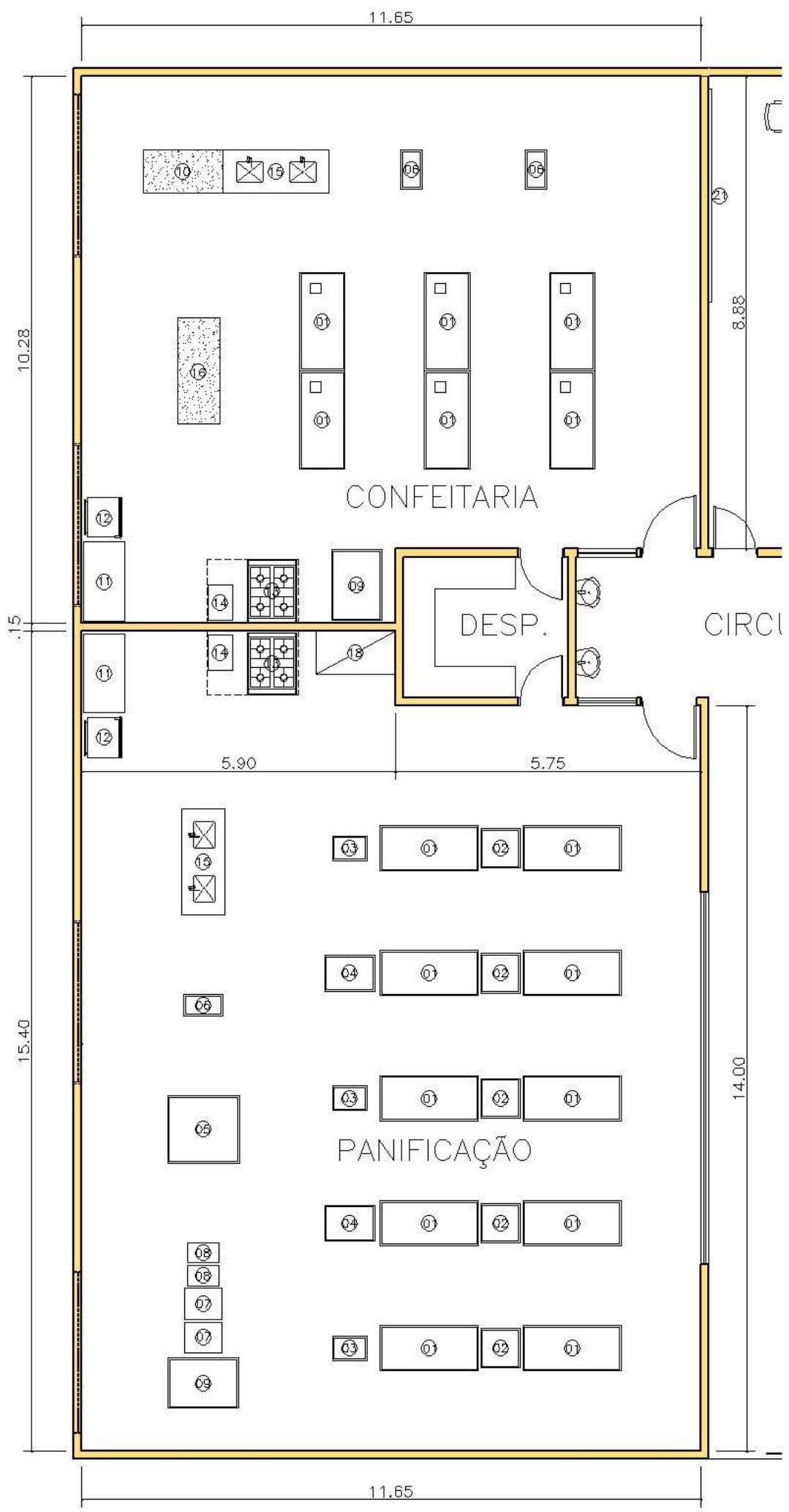

Obs.: Área da padaria 171,40 $\mathrm{m}^{2}$; área da confeitaria 111,70 m² 
Figura 3: Sala de Aula

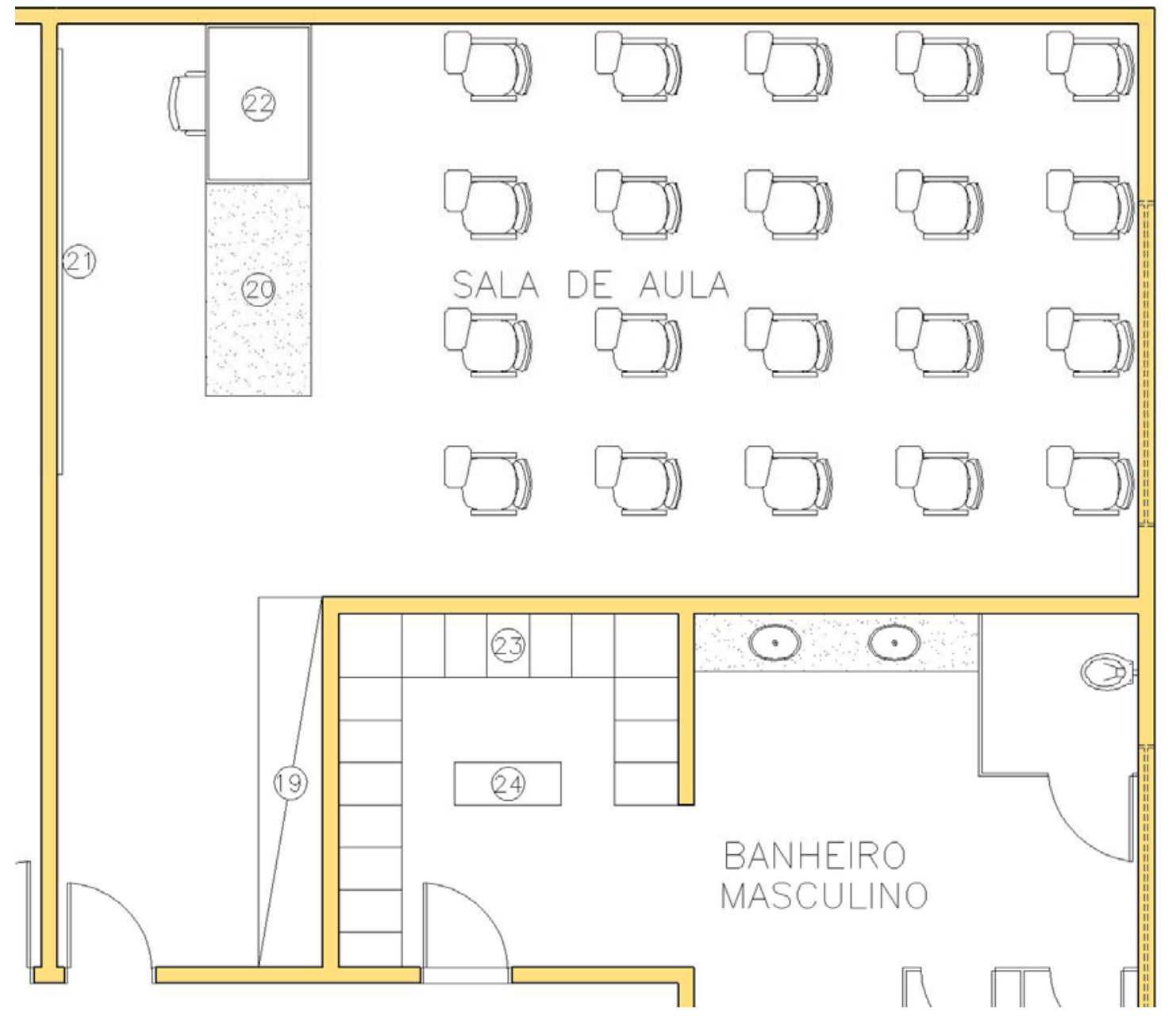


Figura 4: Área destinada às atividades administrativas e acadêmicas.

Obs.: Na sala de coordenação, uma pequena biblioteca.

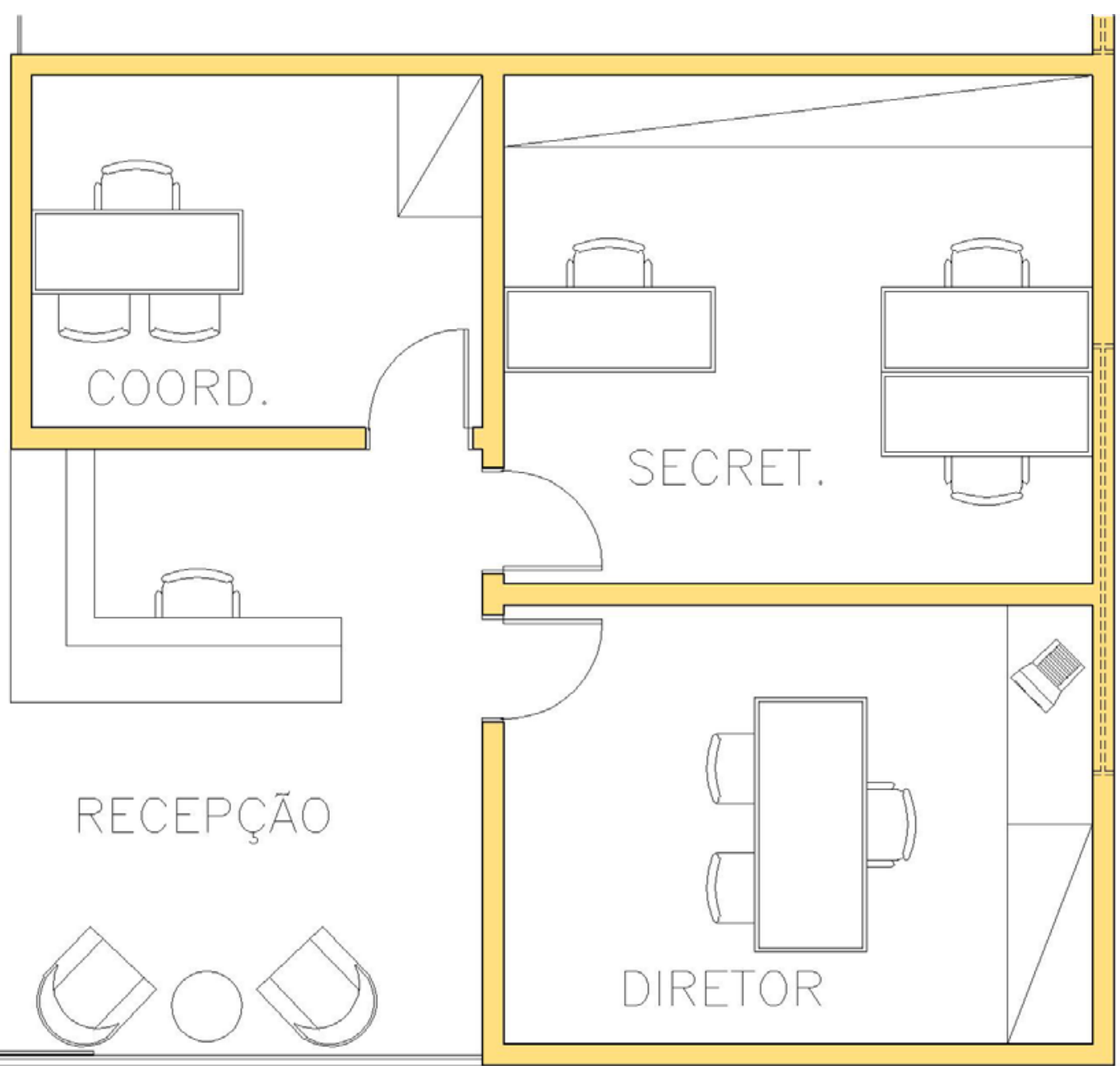


Figura 5: Legenda da planta do Centro Técnico de Treinamento em Confeitaria e Panificação

LISTA DE EQUIPAMENTOS

MOVEIS E EQUIPAMENTOS:

(COMPRIMENTO X PROFUNDIDADE X ALTURA)

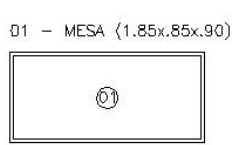

02 - MODELADORA $(.74 \times .74 \times 1.25)$

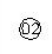

03 - MASSEIRA (.65x.46x.73)

(63)

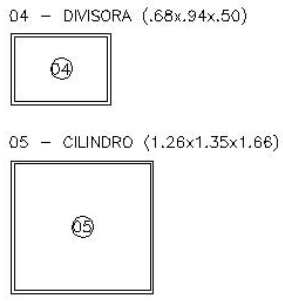

O6 - BATEDEIRA $\langle .40 \times .73 \times .84\rangle$

\section{(6)}

07 - ARMARIO P/ PAO FRANCES $(.58 \times .70)$ (2)

08 - ESQUELETO P/ PAO DOCE (.38x.60) 68
O9 - FORNO ELETRICO $(.94 \times 1.33 \times 1.14)$

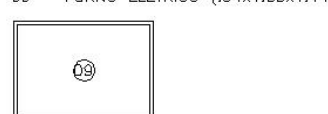
PARA LDOUIFICADOR E PROCESSADOR (1.50x.80x.80)

(10)

11 - FREEZER HORIZONTAL $(1.48 \times .78 \times .96)$

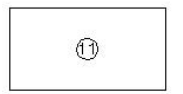

12 - GELADEIRA DUPLEX

$$
\text { (13) }
$$

13 - FOGAO INDUSTRIAL 6 QUEIMADORES (1.37 $\times 1.18 \times .85$ )

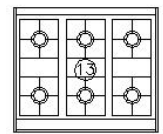

14 - FRITADEIRA ELETRICA $\langle .47 \times, 66 x, 85\rangle$ (14)

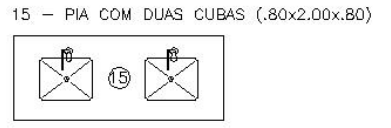

16 - BANCADA EM GRANITO PARA CHOCOLATE COM ARMARIO EMBAIXO $\langle .80 \times 2.00 \times .80)$
7 - BEBEDOURO

(17)

18 - ARMARIO COM 3 PORTAS
PARA UTENSILIOS $(1.50 \times .80 \times 2.10)$

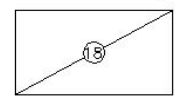

19 - ARMARIO PARA EQUIPAMENTOS, LIVROS,

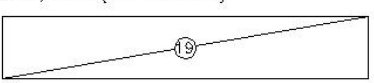

20 - MESA EM GRANITO A DEFI

$-1.00 \times 1.00 \times .80)$
0

20

21 - QUADRO NEGRO $\langle 4.00 \times .05 \times 1.50\rangle$ (21)

22 - MESA EM MADEIRA PARA PROFESSOR (1.50x1.00x.80)

(22)

23 - ESCANINHO PARA ALUNOS E FUNCIONARIOS
(15 EM CADA GANHEIRO)

24 - BANCO EM MADEIRA (1.00x.40x.50)

24 


\subsection{Custo das Máquinas e Equipamentos do Centro Técnico de}

\section{Treinamento}

Tabela 7: Relação de preços das máquinas, equipamentos e utensílios

\author{
Descrição \\ Forno elétrico \\ Modeladora \\ Divisora \\ Amassadeira \\ Cilindro \\ Mesa aço inox \\ Armários p/pão com 20 assadeiras \\ Armários p/pão com 40 assadeiras \\ Batedeira 20 litros \\ Batedeira Planetária \\ Exaustor \\ Geladeira duplex \\ Frezer Horizontal \\ Fritadeira \\ Fogão industrial 4 bocas \\ Mesa com tampão de mármore \\ Armário com 3 portas bancada de mármore \\ Pia com duas cubas \\ Balança digital \\ Balança \\ Utilitários diversos (considerar preço médio) \\ Mesa com tampa de mármore $\mathrm{p} /$ sal de aula \\ Cadeiras para sala de aula \\ Mesa de escritório \\ Cadeiras acolchoadas \\ Armários para sala dos porfessores \\ Armários para o vestuário \\ Prateleiras para despensa \\ Balcão para secretária e bilblioteca \\ Estantes para biblioteca \\ Mesa redonda para biblioteca \\ Livros diversos \\ Mesa para sala dos professores \\ Quadro branco \\ Banco para vestuário \\ Espelho \\ Arquivo pastas suspensas \\ Armários de escritório \\ Acessórios para escritório \\ Outros \\ Sofá \\ Total
}

Fonte: Pesquisa de mercado. Compilação do autor

\begin{tabular}{rrr} 
Quantidade & Valor Unitário & Valor Total \\
2 & $19.800,00$ & $39.600,00$ \\
5 & $3.800,00$ & $19.000,00$ \\
2 & $3.300,00$ & $6.600,00$ \\
3 & $5.490,00$ & $16.470,00$ \\
1 & $8.700,00$ & $8.700,00$ \\
16 & 722,00 & $11.552,00$ \\
2 & 877,00 & $1.754,00$ \\
2 & $1.086,00$ & $2.172,00$ \\
3 & $4.600,00$ & $13.800,00$ \\
6 & 398,00 & $2.388,00$ \\
2 & $1.850,00$ & $3.700,00$ \\
2 & $2.100,00$ & $4.200,00$ \\
2 & 600,00 & $1.200,00$ \\
2 & 460,00 & 920,00 \\
2 & 630,00 & $1.260,00$ \\
1 & $1.200,00$ & $1.200,00$ \\
2 & 730,00 & $1.460,00$ \\
2 & 980,00 & $1.960,00$ \\
1 & 682,00 & 682,00 \\
1 & $1.060,00$ & $1.060,00$ \\
1 & 85,00 & $12.750,00$ \\
150 & $10.000,00$ & $10.000,00$ \\
1 & $1.200,00$ & $1.200,00$ \\
20 & 197,00 & $3.940,00$ \\
5 & 300,00 & $1.500,00$ \\
26 & 198,00 & $5.148,00$ \\
1 & 860,00 & 860,00 \\
2 & $1.100,00$ & $2.200,00$ \\
10 & 95,00 & 950,00 \\
2 & $1.040,00$ & $2.080,00$ \\
8 & 170,00 & $1.360,00$ \\
3 & 280,00 & 840,00 \\
100 & 30,00 & $3.000,00$ \\
1 & 580,00 & 580,00 \\
2 & 415,00 & $1.245,00$ \\
1 & 320,00 & 640,00 \\
$2.000,00$ & $2.000,00$ \\
\hline 0 & 490,00 & 490,00 \\
1 & 450,00 & 900,00 \\
1 & 12,00 & 480,00 \\
2 & & \\
1 & & 193,00
\end{tabular}


Obs.: Devido ao projeto propor a criação de um centro de treinamento modelo ideal, não é necessário neste estudo o levantamento do investimento em construção civil e tão pouco os valores referentes aos custos e a receitas do centro; sugere-se este estudo para uma etapa posterior.

As máquinas, equipamentos, utensílios e móveis acima relacionados atendem às especificações e às exigências das entidades responsáveis pelo setor. Todos os itens orçados são imprescindíveis para o adequado funcionamento do fluxo operacional das atividades propostas. 


\section{CONSIDERAÇÕES FINAIS}

É indiscutível o crescimento da gastronomia em Brasília, nos últimos tempos, apesar da mão-de-obra qualificada ser um fator restritivo a sua expansão. As empresas existentes terão que diversificar, cada vez mais, seus produtos, acompanhando as novidades do mercado, com vistas à manutenção da clientela e à conquista de novos clientes.

O mundo passa por profundas transformações em várias áreas. A velocidade da informação e a disseminação do conhecimento modificam realidades e criam novas tendências. Há um intenso movimento de profissionalização nos mais diversos setores, a fim de que os antigos negócios suportem o novo mercado consumidor e a nova concorrência.

A indústria gastronômica vem conquistando, cada vez mais, posição de destaque no cenário mundial. Essa conquista deve-se à busca dos envolvidos em satisfazer as atuais exigências do público consumidor, sedentos pelo consumo de novos sabores e, principalmente, por produtos de alta qualidade.

Para atender a essa demanda de mercado na gastronomia as cozinhas devem ser mais técnicas, modernas e principalmente, criativas. A busca por resultados que atendam o desejo do mercado consumidor passa pela formação criteriosa de profissionais em nível acadêmico e técnico que possam ser os agentes transformadores desse processo que já se iniciou há alguns anos, mas que insiste em crescer vagarosamente diante da carência de mão-de-obra especializada.

Tendo esse cenário de mudança e maior exigência nos serviços o objetivo geral proposto para este estudo foi fazer uma pesquisa exploratória 
para analisar a viabilidade da criação de um centro de treinamento voltado para formação de profissionais de confeitaria e padaria.

Existem várias instituições atuantes no Brasil, no sentido de apoiar o crescimento das indústrias e valorizar os profissionais perante o mercado.

Quanto às empresas atuantes no ramo, infelizmente não foram obtidas informações precisas sobre o tamanho do setor. Onde havia a expectativa de se obter dados concretos, como por exemplo na Junta Comercial, os dados solicitados não foram disponibilizados; pois foi alegado que o sistema de cadastramento de entidades não classifica as empresas por ramo de atividades. Os dados obtidos nas entidades SIAB, IEL e STIAB não são compatíveis com o número de estabelecimentos do ramo panificação e confeitaria empiricamente observado no dia-a-dia.

Quanto às empresas do Distrito Federal que atuam na capacitação técnica profissional nesse ramo são poucas, resumindo-se a SENAI e SESC que são escolas profissionalizantes e poucos cursinhos isolados em empresas de artigos para festa e escolas de arte culinária que oferecem receitas em troca da compra de mercadoria. Porém, deixam muito a desejar em relação às exigências do mercado que já conhece a qualidade da confeitaria internacional.

O empresário não tem grande aceitação pelos cursos oferecidos, Isto resulta em parte devido à estrutura curricular adotada que só aborda técnicas de produção tradicional, para iniciantes e a oferta de uma programação anual de cursos de curta duração, portanto pouco significativa na formação profissional. Embora algumas dessas instituições tenham credibilidade no mercado, as capacitações por elas oferecidas não servem como modelo e tão pouco como referencial. 
Através da análise mercadológica foi constatada uma contradição entre os registros das entidades e das observações empíricas no dia-a-dia, portanto impossibilitando a definição do exato número de empresas atuantes. Também se observa o nível de qualificação da mão-de-obra, a demanda do mercado por profissionais qualificados e a oferta de cursos de formação técnica disponível. A análise dos dados também demonstrou, entre as necessidades identificadas, a criação de um centro de capacitação. Diante disso, foi elaborada uma proposta para a criação de um centro, tendo como referência a estrutura do Instituto Argentino de Gastronomia conceituado no ramo, que serviu como "benchmark" para a montagem do plano ora proposto.

Disseminar o conhecimento é a proposta deste estudo. Somente dessa forma é possível a manutenção de um crescimento sustentável para esse setor. O profissional brasileiro já provou, em outras áreas, que o saber se transforma por suas mãos, ganhando mais brilho.

O presente estudo também identificou que os empresários e os profissionais pouco investem em programas de qualificação profissional, por entenderem que esta é uma forma de redução dos custos, não tendo, portanto, a percepção correta dos gastos de capacitação como investimento.

Foi constatado nas entrevistas, que alguns empresários participam de treinamentos até no exterior para posteriormente, eles próprios, repassarem os conhecimentos adquiridos aos seus empregados, criando uma relação de dependência com seus colaboradores e assim limitando o campo de conhecimentos dos mesmos.

Diante de tal fato, pode-se inferir que o momento não é tão oportuno para a criação do Centro Técnico de Treinamento em Confeitaria e Panificação 
devido cultura já exposta neste estudo que enfatiza a incompreensão quanto ao custo beneficio por parte dos empregadores e empregados no investimento em qualificação.

Assim sendo, a sugestão é propor um projeto de parcerias com entidades representantes do setor e outras instituições que atuem na área de formação profissional, que juntas poderão implementar o projeto que introduza gradativamente hábitos que alterem a consciência destes empresários e profissionais, criando assim as condições favoráveis para a instalação de um centro como ora proposto. 


\section{REFERÊNCIAS BIBLIOGRÁFICAS}

ARBACHE, Jorge. Economia Brasileira e Gastronomia. In: I Congresso Brasileiro de Gastronomia e Segurança Alimentar, 2004. Brasília.

BELLUZZO, Rosa; HECK, Marina. Doces sabores. São Paulo: Studio Nobel, 2002. 179 p. ISBN 8575530100

BOAVENTURA, Edivaldo M. Como ordenar as idéias. São Paulo: Ática, 1988. $59 \mathrm{p.}$

CARVALHO, Maria Cecília de (Coord.). Construindo o saber: metodologia científica: fundamentos e técnicas. 14. ed. São Paulo: Papirus, 2003. 175 p. ISBN 8530800710

DEMO, Pedro. Pesquisa e informação qualitativa: aportes metodológicos. Campinas: Papirus, 2001. 135 p. ISBN 85-308-0624-7

DOLABELA, Fernando C. O segredo de Luísa. São Paulo: Cultura, 1999. 312 p. ISBN 85-293-0045-9

CASCUDO, Luís da Câmara. História da alimentação no Brasil. São Paulo: Cia Ed Nacional, 1971.

CONSIGLIERI, Carlos. A tradição conventual na doçaria de Lisboa. Portugal: Colares, 1999. ISBN 9727820077

ESPAÇO do consumidor. Origem e história do açúcar. Disponível em:

$<$ http://www.acucarguarani.com.br/consumidor/historia.php $>$ Acesso em 01 dez. 2005.

FERNANDEZ-ARMESTO, Felipe. Comida: uma história. São Paulo: Record, 2004. 362 p. ISBN: 8501065293

FLANDRIN, Jean-Louis; MONTANARI, Massimo. História da alimentação. 2. ed. São Paulo: Liberdade, 1998. 885 p. ISBN 85-7448-002-9

FREYRE , GILBERTO. Açúcar. São Paulo: Cia das Letras, 1977.

FURTADO, Carla. Mercado do luxo requer serviço de diamante. Comunicação \& Marketing. Revista FECOMÉRCIO. Brasília, n. 100, jun. 2005.

GALANTE, MARIANA. Patrimônio paulistano. Revista Gula. São Paulo, n. 157, nov. 2005.

LESNAU, Marcilene Carmen da Silva. Influência portuguesa na doçaria brasileira. 2004. 69 f. Print-out: Monografia (especialização) - Universidade de Brasília, Brasília,2004. 
LIMA, Miguel. Gestão de marketing. Rio de Janeiro: Fundação Getúlio Vargas, 2003.

OKAMOTTO, Paulo. Constante aperfeiçoamento: opinião. Revista Fecomércio, Brasília, n. 96, p.11, dez. 2004 / jan. 2005.

OLIVEIRA, Marco Antônio Garcia. E agora, José? São Paulo: Senac, 1999. 494 p. ISBN 85-7359-079-3

PERRELLA, Ângelo Sabatino; PERELLA, Myrian Castanheira. A história da confeitaria no mundo. Campinas: Ed. Livro Ltda. Brasil, 1999.

PONCHIROLLI, Osmar. Capital humano: sua importância na gestão estratégica do conhecimento. Curitiba: Ed. Juruá, 2005. 184 p. ISBN 853621015-X

QUALIDADE Di Lorenza. Disponível em : < http://www.torteiradilorenza.com.br/in?area inst web=historia> Acesso em 02 dez. 2005.

REVISTA FIBRA. SIAB qualifica empregados e trabalhadores. Brasília:SESI, $\mathrm{n}$. 15, nov. 2004.

RODRIGUES Antonio. Brusque, paraíso do café colonial. Disponível em: <http://na.uol.com.br/2001/jun/27/0tur.htm> Acesso em: 01 dez. 2005.

SANTOS, Saionara da Graça Freitas. Treinando manipuladores de alimentos. São Paulo: Varela, 1999.

SARAMAGO, A.; FIALHO, M. Doçaria dos conventos de Portugal. Lisboa: [s. n.], 1977.

SEBRAE; FUBRA. Fatores condicionadores e taxa de mortalidade de empresa no Brasil. Relatório de Pesquisa. Brasília: 2004.

SENAC. Referenciais para a educação profissional: Senac 2001. Rio de Janeiro, 2001. 79 p.

TEAD, Ordway. A arte da administração. 2. ed. Rio de janeiro: Fundação Getúlio Vargas, 1970. 212 p.

TUTORIA 72 - Galeria de imagens. Confeitaria Colombo. Disponível em: <http://www.imasters.com.br/conteudo2/moliveira/10/emplo.htm>. Acesso em: 01 dez. 2005.

ÚNICA. Açúcar: os tipos de açúcar. Disponível em: <http://www.unica.com.br/pages/acucar_tipos.asp> Acesso em 01 dez. 2005. 
USINA Ester. O Processo de fabricação de açúcar e álcool na Usina Ester. Disponível em < http://www.usinaester.com.br/Produtos/Produtos.html> Acesso em: 01 dez. 2005.

VERGARA, Sylvia Constant. Gestão de pessoas. 4. ed. São Paulo: Atlas, 2005. 213 p. ISBN $852244031 X$ 